Illinois State University

ISU ReD: Research and eData

Theses and Dissertations

$3-27-2020$

\title{
The relationship between Sense of Community and Job satisfaction among employees in Campus Recreation Center
}

Mina Woo

Illinois State University, mina9634@gmail.com

Follow this and additional works at: https://ir.library.illinoisstate.edu/etd

Part of the Recreation, Parks and Tourism Administration Commons, and the Tourism Commons

\section{Recommended Citation}

Woo, Mina, "The relationship between Sense of Community and Job satisfaction among employees in Campus Recreation Center" (2020). Theses and Dissertations. 1229.

https://ir.library.illinoisstate.edu/etd/1229

This Thesis is brought to you for free and open access by ISU ReD: Research and eData. It has been accepted for inclusion in Theses and Dissertations by an authorized administrator of ISU ReD: Research and eData. For more information, please contact ISUReD@ilstu.edu. 


\section{THE RELATIONSHIP BETWEEN SENSE OF COMMUNITY AND JOB SATISFACTION AMONG EMPLOYEES IN CAMPUS RECREATION CENTER}

\section{MINA WOO}

64 Pages

The purpose of this study was to investigate the relationship between Sense of Community (SOC) and job satisfaction of employees in Campus Recreation Center (CRC), and the impact of demographic information, including gender, job position, and job tenure, on the extent of their SOC and job satisfaction. This study utilized quantitative method and developed a questionnaire with two scales: Spector's (1985) Job Satisfaction Survey (JSS), and Sense of Community Index 2 (SCI-2) created by Chavis, Lee, and Acosta (2008). The results indicate positive correlation between SOC and job satisfaction among the employees in CRCs. On the other hand, the results do not support that the employees' demographic information influence on the levels of SOC and job satisfaction. However, the results reveal that job position influences on three of nine factors of job satisfaction, which are fringe benefits, operating conditions, and coworker. The results have implications in campus recreation settings, by providing insights for professionals in campus recreation to enhance not only the levels of SOC or job satisfaction of employees at CRCs but also their retention.

KEYWORDS: Sense of Community; Job Satisfaction; Employee; Campus Recreation Center 
THE RELATIONSHIP BETWEEN SENSE OF COMMUNITY AND JOB SATISFACTION AMONG EMPLOYEES IN CAMPUS RECREATION CENTER

MINA WOO

A Thesis Submitted in Partial

Fulfillment of the Requirements

for the Degree of

MASTER OF SCIENCE

School of Kinesiology and Recreation

ILLINOIS STATE UNIVERSITY

2020 
(C) 2020 Mina Woo 
THE RELATIONSHIP BETWEEN SENSE OF COMMUNITY AND JOB SATISFACTION AMONG EMPLOYEES IN CAMPUS RECREATION CENTER

MINA WOO

COMMITTEE MEMBERS:

Yun Chang, Chair

Michael A. Mulvaney

Tracy Mainieri

Dawn A. Pote 


\section{ACKNOWLEDGMENTS}

I would like to express appreciation to the Chair of my thesis committee, Dr. Chang, for her support, guidance, and encouragement. She always has shown her faith in me and encouraged me to write properly with her critical feedback, guidance, and support. Also, I am grateful to Dr. Mulvaney and Dr. Mainieri for teaching and support. Their teaching allowed me to extend my knowledge in recreation, and critical comments helped me to broaden my point of view not only in the thesis but also scholarship. I would also thank Ms. Pote, who gave me opportunities to work in different positions in ISU Student Fitness Center. Also, I would thank the managers in campus recreation centers, who participated in the survey to contribute the research.

I would thank my family for love and support. Thanks to them, I did not give up and was able to start studying at ISU. Also, I am grateful to my mother in law, Gyeonghee Park, for ongoing support and faith in me. Lastly, I would thank my husband, Incheol Jang, for giving me ongoing love and support. He always gives me both immediate and critical feedbacks and allows me to challenge myself to think differently and grow the capability as a better scholar. This thesis could not have been written without your faith and help. Thank you, Incheol. I love you.

M.W. 


\section{CONTENTS}

Page

ACKNOWLEDGEMENTS

TABLES

CHAPTER I: INTRODUCTION 1

CHAPTER II: LITERATURE REVIEW 4

Campus Recreation Center $\quad 4$

Employees in CRCs $\quad 6$

$\begin{array}{ll}\text { Sense of Community (SOC) } & 7\end{array}$

Job Satisfaction 9

SOC and Job Satisfaction $\quad 13$

CHAPTER III: METHODODOLOGY 16

$\begin{array}{ll}\text { Participants } & 16\end{array}$

$\begin{array}{ll}\text { Instrumentation } & 17\end{array}$

$\begin{array}{ll}\text { Job Satisfaction Survey (JSS) } & 17\end{array}$

Sense of Community Index 2 (SCI-2) 18

$\begin{array}{ll}\text { Demographics Questions } & 19\end{array}$

Qualtrics XM $^{\text {XM }} 19$

$\begin{array}{ll}\text { Sampling Methods } & 19\end{array}$

$\begin{array}{ll}\text { Data Collection } & 20\end{array}$

$\begin{array}{ll}\text { Data Analysis } & 21\end{array}$

CHAPTER IV: RESULTS 22

Sample Size and Data Screening 22 
Descriptive Statistics of SOC and Job Satisfaction 23

$\begin{array}{ll}\text { Hypothesis } 1 & 25\end{array}$

$\begin{array}{ll}\text { Hypothesis } 2 & 25\end{array}$

Gender and CRC Employees' SOC $\left(\mathrm{H}_{2-1}\right)$

Job Position and CRC Employees' SOC $\left(\mathrm{H}_{2-2}\right)$

Job Tenure and CRC Employees' SOC $\left(\mathrm{H}_{2-3}\right) \quad 27$

$\begin{array}{ll}\text { Hypothesis } 3 & 28\end{array}$

Gender and CRC Employees’ Job Satisfaction $\left(\mathrm{H}_{3-1}\right)$

Job Position and CRC Employees’ Job Satisfaction $\left(\mathrm{H}_{3-2}\right)$

Job Tenure and CRC Employees' Job Satisfaction $\left(\mathrm{H}_{3-3}\right)$

CHAPTER V: DISCUSSION

The Relationship Between SOC and Job Satisfaction of CRC Employees 33

The Influence of Demographic Information on CRC Employees' levels of SOC 34

The Influence of Demographic Information on CRC Employees’ levels of Job

$\begin{array}{ll}\text { Satisfaction } & 35\end{array}$

$\begin{array}{ll}\text { Limitations } & 36\end{array}$

Implications and Recommendations $\quad 37$

$\begin{array}{ll}\text { Conclusions } & 38\end{array}$

$\begin{array}{ll}\text { REFERENCES } & 40\end{array}$

APPENDIX A: QUESTIONNAIRE 
Table

\section{TABLES}

1. Subscale Contents for the Job Satisfaction Survey 18

2. Subscale and items for Sense of Community Index 2

3. Sample Demographics 23

4. Descriptive Statistics of SOC of the employees in CRCs 24

5. Descriptive Statistics of Job Satisfaction of the employees in CRCs 25

6. Pearson Correlation Coefficient of SOC and job satisfaction 25

7. Independent Sample t-test of gender and SOC 26

8. Multivariate Tests of gender and SOC 26

9. Independent Sample t-test of job position and SOC 27

10. Multivariate Tests of job position and SOC 27

11. Independent Sample t-test of job tenure and SOC 28

12. Multivariate Tests of job tenure and SOC 28

13. Independent Sample t-test of gender and Job satisfaction 29

14. Multivariate Tests of gender and Job satisfaction 29

15. Independent Sample t-test of job position and Job satisfaction 30

16. Multivariate Tests of job position and Job satisfaction 31

17. Tests of Between-Subjects Effects of job position and nine subsets of job satisfaction 31

18. Independent Sample t-test of job tenure and Job satisfaction 32

19. Multivariate Tests of job tenure and Job satisfaction 32 


\section{CHAPTER I: INTRODUCTION}

Campus recreation has positively influences students' lives. Considering the value of campus recreation, the campus recreation center $(\mathrm{CRC})$ has been regarded as an important place in universities (Miller, 2011). A line of researchers found that students can enhance physical and psychological health as they participate in campus recreation programs and use CRCs (Forrester, 2015; Henchy, 2013). Omar-Fauzee, Yusof, and Zizzi (2009) stated that students adopt healthy behaviors for campus life and adulthood through the use of CRCs. Bryant, Banta, and Bradley (1995) also found that students who engage in recreation programs experience the benefits of stress reduction, self-confidence, and friendships based on meeting people at CRCs. Other benefits found from using campus recreation programs include improved academic performance (Todd, Czyszczon, Carr, \& Pratt, 2009), social interactions (Henchy, 2011), and school retention (Lindsey \& Sessoms, 2006; Kampf \& Teske, 2013). The study of Roddy et al. (2017) also revealed data on gender differences in response to CRCs, where female students who utilized these facilities more often had higher GPAs on average than those who didn't.

As positive influences of campus recreation and CRCs are considered crucial to campuses, scholars have been interested in examining specific aspects of recreation programs and campus recreation facilities that contribute to students (Artinger, Clapham, Hunt, Meigs, Milord, Sampson, \& Forrester, 2006; Bryant et al., 1995; Lindsey \& Sessoms, 2006). In the study of Artinger et al., (2006), recreation programs are found to assist students in being involved and integrated into campus life. Lindsey and Sessoms (2006) stated that both recreation programs and recreation facilities influence students' decision to stay in college. Zizzi, Ayers, Watson, and Keeler (2004) showed that newly built CRCs improved both student satisfaction in and overall use of these facilities. 
Employees who work at CRCs have also been investigated by scholars (McFadden \& Carr, 2015; Kaltenbaugh, 2009). These employees are composed of student employees and professional employees (Kampf, 2013), where the majority of the workforce in CRCs are students (Bower, Hums, \& Keedy, 2005). Student employees work in diverse positions, such as lifeguards, member service representatives, facility assistants, and fitness trainers and many have experienced personal growth and developed valuable work skills while employed at CRCs (McFadden \& Carr, 2015). While professional employees often supervise student employees while managing programs and facilities at CRCs (Kaltenbaugh, 2009), the combination of both groups, including full-time and part-time employees, are crucial to their success (Kampf, 2013).

Given a reliance on both student and professional employees at CRCs, it is important to understand job satisfaction to help retain current workers. Mull, Bayless, and Jamieson (2005) explained that the employees who meet specific standards and specialization needs in the program are crucial to operating recreational sports and programs in CRCs. Accordingly, a lot of time and resources for recruitment and career development are required when a CRC hires new employees (Mull et al., 2005). Given that job dissatisfaction is the main contributor to employee turnover (Mobley, Griffeth, Hand, \& Meglino, 1979), researchers (Pack, Jordan, Turner, \& Haines, 2007; Kaltenbaugh, 2009; Kearney \& Tingle, 1998; Kellison \& James, 2011) have focused on several factors related to job satisfaction of employees at CRC, such as organizational support (Pack et al., 2007), nature of the work (Kaltenbaugh, 2009), job titles (Stier, Schneider, Kampf, \& Gaskins, 2010), and coworkers (Kellison \& James, 2011). Kellison and James (2011) found that the relationship with other coworkers also influences the employees' job satisfaction, where the sense of community (SOC) created in work and these settings influences employees' job satisfaction. 
Previous scholars have suggested employees' SOC as a factor for their job satisfaction since SOC influences employees' communication, health, and satisfaction of work (Klein \& D’Aunno, 1986; Royal \& Rossi, 1996; Pretty, McCarthy, \& Catano, 1992). According to Klein \& D’Aunno (1986), SOC at the workplace contributes the employees to have enhanced communication with coworkers, which increases efficiency of the work. This helps employees better understand their job and reduce the employees' stress related to work (Royal \& Rossi, 1996). Given the benefits, Klein and D'Aunno (1986) insisted that if employees feel higher SOC at work, they may be more satisfied with their job. Many scholars in health care (Lampinen, Viitanen, \& Konu, 2015), and education (Rossi \& Stringfield, 1995; Winter-Collins \& McDaniel, 2000), investigated the relationship between employees' SOC and their job satisfaction. As a result, it was found that the level of employees' SOC influences not only job satisfaction and job retention (Chatman, 1991) but also organizational commitment and intention to stay at the workplace (Milliman, Czaplewski, \& Ferguson, 2003).

While these studies examining SOC of the workforce provide insights into job satisfaction, to the best of my knowledge, there is little research that studies SOC as an influencer for job satisfaction of CRC employees. This study thus aims to extend knowledge of the workforce at $\mathrm{CRC}$ by investigating the relationship between job satisfaction and SOC created at these facilities and if the level of SOC or job satisfaction is influenced by their demographic information. 


\section{CHAPTER II: LITERATURE REVIEW}

\section{Campus Recreation Center (CRC)}

Campus Recreation Center is considered as vital facilities where students can obtain numerous benefits for their school and personal life on campus that go beyond fitness objectives. Dalgarn (2001) defined the CRC as a place to "aid in the development of the whole person by providing opportunities to recreate, relax, relieve stress and renew perspective" (p. 68). Students can not only exercise but also interact with classmates while they participate in programs. Other scholars found the use of CRCs positively influences students' lives in diverse ways, such as enhancing academic performance (Belch, Gebel, \& Maas, 2001; Todd et al., 2009), promoting psychological as well as physical health (Haines, 2001; Bryant et al., 1995), enhanced engagement in social interactions (Dalgarn, 2001; Artinger et al., 2006; Miller, 2011), and improving college retention rates (Hall, 2006; Miller, 2011; Kampf \& Teske, 2013).

Academic achievement has been examined as one of the important benefits of the use of CRCs. Many scholars have examined the relationship between the utilization of CRCs and academic achievements of students (Todd et al., 2009; Huesman, Brown, Lee, Kellogg, \& Radcliffe, 2007; Roddy, Pohle-Krauza, \& Geltz, 2017). Todd and colleagues (2009) investigated student academic performance based on the frequency of CRC visits through the quantitative method. Results indicated that those who used CRC above three times a week had a better GPA compared to non-users and low users (Todd et al., 2009).

A range of physical and psychological health are found to be common benefits provided by CRCs. Zizzi et al. (2004) stated the facilities have the potential to encourage students to adopt and keep regular physical activity patterns. As students utilize CRCs, they can build healthy behaviors for adulthood, decrease chronic health disease, and enhance overall health. (Omar- 
Fauzee et al., 2009; Forrester, 2015). Several scholars found positive influences on the psychological health of students (Henchy, 2011; Miller, 2011), where the benefits related to psychological health include increased self-esteem (Dalgarn, 2001), reduction of anxiety and stress (Henchy, 2011), and enhanced social involvement (Miller, 2011).

CRCs also play a role in enhancing students' social integration and sense of community. According to Wolf-Wendel, Ward, and Kinzie (2009), social integration includes relationships interaction with peers and staff as well as involvement in academic or non-academic activities. Dalgarn (2001) claimed that students could also enhance interpersonal skills, social relationships, and self-respect during participation in CRC activities. Zizzi et al. (2004) found that students can more easily make the transition from adolescent to adulthood with support from peers as they build SOC with others at CRCs. The students who had a higher level of social integration are also more likely to continue their academic studies and achieve overall success in their lives (Tinto, 1975).

CRCs can influence the retention of students and their college choice, where freshmen in particular make the availability of these facilities as one of their priorities in enrollment decisions (Kampf, 2010; Bryant et al., 1995; Hesel, 2000). The availability of recreation programs and CRCs is also an important element for enrolled undergraduate students when deciding to stay in the college (Haines, 2001). Due to this priority, the presence of a CRC helps universities recruit students and overcome problems related to retention (Omar-Fauzee et al., 2009). Miller (2011), for example, found that the influence of CRC activities on student retention includes an increased satisfaction with their university, which helps them to stay in school. 


\section{Employees in CRCs}

As the $\mathrm{CRC}$ relies on both student and professional employees to manage all programs and services, employees are in charge of a wide range of operations for those generally interested in physical health as well as athletes (McFadden \& Carr, 2015). Each position and type of duties naturally have different requirements, including experience and education levels (Kampf, 2013). Professional CRC employees are generally responsible for overall operations of campus program and facilities, including management of student workers and operating budgets (Mull et al., 2005). For instance, campus recreation administrators may adjust their budget to improve program efficiently based on limited resources (Zhang, DeMichele, \& Connaughton, 2004). Management of CRC student workers is an important component of professional employee duties, where they work in recruiting, training, and organizing schedules for student employees (Mull et al., 2005).

Student employees are an important workforce at CRCs, where in most cases, they make up the majority of the workforce (Bower et al., 2005). These employees work in diverse positions, such as outdoor adventure supervisors, intramural sports officials, and sport club supervisors. McFadden and Carr (2015) found that student employees perform other essential duties, such customer services, facilitating programs, instructing various recreational activities, and leading sports clubs. This means that student employees learn important skills while they work at CRCs, where benefits include professional development and enhanced socialization (Griffith, Walker, \& Collins, 2011; Ehrenberg \& Sherman, 1987) that includes SOC. Griffith et al. (2011) found that student employees who experience SOC during work hours learn to build a more effective work environment and services for the entire campus community as well as diverse student development programs. 


\section{Sense of Community (SOC)}

Many studies have found that that students could increase SOC while they utilize CRC facilities and programs (Darglarn, 2001; Hall, 2006; Royal \& Rossi, 1996; Pretty \& McCarthy, 1991; Lambert \& Hopkins, 1995). Sarason (1974) defined the psychological SOC as a feature of communities that promote cognition of similarities among individuals and the propensity to promote and maintain interdependence and the feeling of belonging to a larger and more secure, dependable, and concrete social structure. Since Sarason (1974) defined psychological SOC, many scholars (McMillan \& Chavis, 1986; Rovai, 2002; Glynn, 1981) became interested in this concept. McMillan and Chavis (1986) expanded Sarason's definition of this SOC to include "a feeling that members have of belonging, a feeling that members matter to one another and to the group, and a shared faith that members' needs will be met through their commitment to being together" (p. 9).

On the basis of this extended definition, McMillan and Chavis (1986) provided a theoretical framework of SOC composed of four components: (a) membership, (b) influence, (c) integration and fulfillment of needs, and (d) shared emotional connection. They explained that membership is a feeling of belonging to a community, which can be enhanced by the interaction of different sub-elements such as boundaries, emotional safety, and a sense of inclusion, which includes the sense of belonging to and being accepted by others (Legg, Wells, \& Barile, 2015). Influence refers to the feeling that an individual experiences when she or he can make a difference in the community. It is a bidirectional concept, so not only the individual but also the community exerts influence on each other (McMillan, 2011). Integration and fulfillment of needs means that the needs of members are being met as the community provides rewards or resources to members (McMillan \& Chavis, 1986). Lastly, shared emotional connection is based on history 
and experience based on time spent with members in the community. This connection is also based on the history, experience, and events that members share within the community where they do not need to experience history together, but should recognize shared values (McMillan $\&$ Chavis, 1986). SOC that employees experience in the course of their work has also been found to be one of the key influences on their productivity and quality of work (Royal \& Rossi, 1996; Klein \& D’Aunno, 1986, Chatman, 1991).

SOC has been examined by numerous scholars in diverse fields, such as community development (Wood, Frank, \& Giles-Corti, 2010; Gomez, Baur, Hill, \& Georgiev, 2015), education (McInnerney \& Roberts, 2004; Rovai \& Jordan, 2004), and recreational sports (Huesman, Brown, Lee, Kellogg, \& Radcliffe, 2009; Dalgarn, 2001). In examining the relationship among SOC, walking, and characteristics of the neighborhood, Wood et al. (2010) found that SOC positively influenced both leisure walking and design of the neighborhood. Yet SOC is not dependent entirely on face-to-face relationships. For example, McInnerney and Roberts (2004) reported that SOC that is created during participation in an online course could help students feel less isolation and assist their learning process. Yasuda (2009) also added that SOC is connected to student integration into the campus community, which helps them to complete their degree studies. In examining the relationship between job satisfaction and SOC at the workplace among the employees in health-care service, Lampinen et al., (2015) reported that SOC positively influenced the job satisfaction of employees.

Other scholars have found that the demographics of employees in the workplace can influence their SOC. For example, Lambert and Hopkins (1995) found various gender differences related to workplace SOC, where women more than men felt that influence in decision-making, formal benefits provided by employers, and supportive family policies were 
more important, while men valued supervisor and group work support more than women. Pretty and McCarthy (1991) found that involvement with others and peer support were key predictors of SOC for male mangers, while SOC based on supervisor support and work pressure that positively impacted male managers had negative outcomes for women supervisors.

\section{Job Satisfaction}

Job satisfaction has been defined by scholars as an individuals' evaluation of their job and work environment (Weiss \& Cropanzano, 1996), the way people feel about work (Spector (1985), and "a pleasurable or positive emotional state resulting from the appraisal of one's job or job experiences" (Locke, 1976, p. 1,300). Newstrom (1986) noted that job satisfaction is based on a complex mixture of favorable or unfavorable emotions that employees experience at work.

Job satisfaction can be affected by diverse demographic factors, including age (Lee \& Wilbur, 1985; Rhodes, 1983; Lee \& Wilbur, 1981; Hochwarter, Ferris, Perrewe, Witt, \& Kiewitz, 2001), sex (Schuler, 1975; Sloane \& Williams, 2000) and education (Glenn \& Weaver, 1982; Ganzach, 2003). In examining whether gender difference and location of the workplace affect job satisfaction of teachers at public high schools, Azhar and Asdaque (2011) proposed that female teachers had higher job satisfaction compared to male teachers. Lee and Wilbur (1985) investigated the relationship between age, education, job tenure, salary, and job satisfaction among employees of different ages, where younger employees expressed less satisfaction with their work compared to older employees.

Employee job satisfaction has been studied in relation to individual characteristics such as personality (Judge, Bono, \& Locke, 2000; Templer, 2012). Templer (2012) stated that some personality characteristics, such as agreeableness, extraversion, and conscientiousness, influenced employees' job satisfaction and motivation in the workplace (Furnham, Eracleous, \& 
Chammorro-Premuzic, 2009). Ilies and Judge (2004) posited that there is also relationship between daily mood and job satisfaction.

Job characteristics have been regarded as another key influencer for job satisfaction, including salary (Judge, Piccolo, Podsakoff, Shaw, \& Rich, 2010; Green \& Heywood, 2008), tenure (Ng \& Feldman, 2010), workload (Jex \& Beehr, 1991; Butt \& Lance, 2005), control (Dwyer \& Ganster, 1991; Chen \& Silverthorne, 2008), and work schedule (Pierce \& Newstrom, 1982; Krausz, Sagie, \& Bidermann, 2000; Kinzl, Knotzer, Traweger, Lederer, Heidegger, \& Benzer, 2004). In terms of salary, Singh and Loncar (2010) looked at the relationship between payment, job satisfaction, and turnover among nurses, where no relationship between payment and job satisfaction was found. On the other hand, Bamundo and Kopelman (1980) identified a positive relationship between education level, salary, tenure, and job satisfaction. Krausz et al., (2000) also noted that accommodating preferred work schedules positively influences employee work attitude.

Previous research has investigated workplace conditions related to job satisfaction (Lund, 2003; McCalister, Dolbier, Webster, Mallon, \& Steinhardt, 2006). In studying the influence of organizational culture on marketing professionals' job satisfaction, Lund (2003) revealed a positive relationship among employees who worked in adhocracy cultures but showed a negative relationship in hierarchical cultures (Lund, 2003). Numerous scholars have explored how employees could be influenced by support from coworkers and supervisors at the workplace. McCalister et al., (2006) found that employees could be influenced by the support from coworkers and supervisors at the workplace. Ducharme and Martin (2000) similarly examined they ways in which coworkers' support influences their job satisfaction, where such support was not found to buffer negative job stress, but improved their job satisfaction (Ducharme \& Martin, 
2000). Brewer, Carnes, and Garner (2007) added that cooperative attitudes among coworkers developed a more positive work environment.

Based on the variables for job satisfaction, its different potential effects can be perceived by employees in various ways depending on the individual (Spector, 1985). These potential effects include job performance (Iaffaldano \& Muchinsky, 1985; Judge, Thoresen, Bono, \& Patton, 2001), frequent absence (Porter \& Steers, 1973; Siu, 2002), turnover (Randhawa, 2007; Ghiselli, La Lopa, \& Bai, 2001), retention (Cowin, 2002; Cowin, Johnson, Craven, \& Marsh (2008), burnout (Scanlan \& Still, 2013; Brackett, Palomera, Mojsa-Kaja, Reyes, \& Salovey, 2010), physical health (Faragher, Cass, \& Cooper, 2005; Ioannou, Katsikavali, Galanis, Velonakis, Papadatou, \& Sourtzi, 2015), psychological well-being (Wright \& Bonett, 2007; Brief, Burke, George, Robinson, \& Webster, 1988), and life satisfaction (Judge \& Watanabe, 1993; Ghiselli et al., 2001). Jacobs and Solemon (1977) found that job satisfaction can lead to improved job performance when organizations provide rewards for great job performance, while employee's job dissatisfaction can naturally be expected to cause turnover (Mobley et al., 1979). With the acknowledgment of the influencers and potential effects of job satisfaction, researchers have been interested in the job satisfaction of employees (Spector, 1985). Many studies have focused on job satisfaction among human service workers compared to workers in industries in the late 1970s (e.g., Frontz, 1978; Zaharia \& Baumeister, 1979; Cherniss \& Egnatios, 1978) and factors of job satisfaction (e.g., Folkins, O'Reilly, Roberts, \& Miller, 1977; Sarata \& Jeppesen, 1977). It has been difficult, however, to apply the job satisfaction scales used for human service organizations to other organizations (Spector, 1985). In order to deal with this problem, some researchers (Smith, Kendall, \& Hulin, 1969; Weiss, Dawis, England, \& Lofquist, 1967; Hackman \& Oldham, 1975; Spector, 1985) developed job satisfaction scales across 
organizations. Smith et al. (1969) proposed the Job Descriptive Index, composed of five facets including work, pay, promotion, supervision, and coworkers. Weiss et al. (1967) created the Minnesota Satisfaction Questionnaire composed of 20 facets. Hackman and Oldham (1975) developed the Job Diagnostic Survey to measure jobs, motivation, job tasks, personality, psychological states, and reaction to jobs. The Job Descriptive Index created by Smith et al. (1969) has been utilized extensively in the literature.

One of the most widely applied instruments is the Job Satisfaction Survey (JSS) developed by Spector (1985) was designed for organizations such as non-profit and public groups as well as human resource organizations. It is composed of the nine sub-facets: pay, promotional opportunities, fringe benefits, contingent rewards, supervision, coworkers, nature of work, communication, and work conditions. Spector (1985) developed JSS for two reasons: to make the existing scales applicable to a wider range of organizations and to cover all the areas of interest (Spector, 1985). While there has been some criticism of the application of a few JSS items (Buffum \& Konick, 1982), many researchers in different sectors and settings have utilized the JSS to examine job satisfaction (Anari, 2012; Franek and Vecera, 2008). These settings include education (Astrauskaite, Vaitkevicius, \& Perminas, 2011; Anari, 2012), general organizations (Franek \& Vecera, 2008), and campus recreation groups (Kaltenbaugh, 2009). Franek and Vecera (2008) examined the relationship between personal characteristics and job satisfaction and found that employees' personal traits, such as stability, openness, agreeableness, and self-efficacy, were associated with job satisfaction. In exploring job satisfaction of secondary school teachers, Astrauskaite et al. (2011) revealed the relationship between Spector's (1985) three JSS subscales: promotion, supervision, and nature of work. Kaltenbaugh (2009) also explored job satisfaction of campus recreation administrators based on the JSS. Kaltenbaugh 
(2009) found that campus recreation administrators' job satisfaction was highly related to the two scales of supervision and nature of work.

\section{SOC and Job Satisfaction}

Today, the workplace is acknowledged as a vital community for employee relations and personal development (Mahipalan \& Sheena, 2018; Klein \& D’Aunno, 1986). It is described by Burroughs and Eby (1998) as a geographic location where employees regularly meet and build their networks formally or informally to share their common association. SOC at the workplace may provide a variety of benefits, such as inherent satisfaction, improvement of health, and enhanced communication among coworkers (Klein \& D’Aunno, 1986). Klein and D'Aunno (1986) stated that employees experiencing SOC at the workplace may associate it with work gratification, enhanced communication between employees, and enhanced quality of work. Royal and Rossi (1996) also claimed that individuals' SOC could bring important results for quality of work experiences. Kirmeyer (1988) proposed that employees become supportive of each other and enhance friendships through social opportunities and task-related communication at the workplace.

In terms of inherent satisfaction, Klein and D'Aunno (1986) stated that when employees experience SOC, especially related to membership involvement, subgroups, and organizations, they perceive not only enhanced self-esteem but also increased job satisfaction. SOC in the workplace can help employees improve not only effective communication (Royal \& Rossi, 1996) but also psychological health (Klein \& D’Aunno, 1986). Royal and Rossi (1996) explained that when employees feel SOC at work, they are more likely to have effective communication, which may result in better understanding of job responsibilities and reduced job burnout. The study of Pretty et al. (1992) that looked at gender differences in psychological and environmental 
burnout, indicated that female non-managers report the highest levels of all burnout, though SOC at the workplace is related to a reduced feeling of burnout for male and female employees. Also, Ivancevich \& Matteson (1980) found that organizations benefit from the improvement of employee's health, such as less payment for health care and fewer absences through employees' SOC.

The correlation between SOC and job satisfaction among employees has been investigated by many scholars (Lampinen et al., 2015; Royal \& Rossi, 1996; Klein \& D’Aunno, 1986) in different settings, such as education (Rossi \& Stringfield, 1995; Winter-Collins \& McDaniel, 2000) and health care (Lampinen, et al., 2015). Chatman (1991) found that the extent to which an individual's experience of SOC at the workplace may be associated with greater job satisfaction, identification to the workplace, and job retention. Pretty and McCarthy (1991) also added that SOC that employees experience at the workplace influenced their tenure. In a unique study exploring spirituality at the workplace and employee attitudes, Milliman, Czaplewski, and Ferguson (2003), employees' SOC was significantly related to intention to quit, job satisfaction, involvement, and organizational commitment, where a positive association can be made between spirituality at work and employee job outcomes.

While a growing body of research has examined a variety of CRCs' impacts (Bryant et al., 1995; Dalgarn, 2001) on students or users, scholars have shown less interest in specific relationships between SOC and campus recreation facilities, programs, and employees (McFadden \& Carr, 2015; Kampf, 2013). Some have studied various characteristics of CRC employees, but there is still room for further research. In business and other disciplines, researchers have applied SOC and job satisfaction for diverse purposes such as employees' retention (Hall, 2006; Miller, 2011) and job performance (Jacob \& Solemon, 1977; Judge et al., 
2001). To my best knowledge, however, there is no research that examines CRC employees' SOC and job satisfaction and the relationship between them. This study can thus contribute to our understanding of $\mathrm{CRC}$ employees and theories of SOC and job satisfaction. From the perspective of practitioners, this research can help them create strategies to increase retention and job performance of CRC employees, while scholars in recreation and other fields may extend the body of knowledge of SOC and job satisfaction theories based on this research.

This study addresses the following three hypotheses:

H1: The CRC employee's SOC will have a positive relationship with their job satisfaction.

H2: The CRC employees' SOC might vary in accordance with their demographic information, including gender, job position, and job tenure.

$\mathrm{H}_{2-1}$ : Gender of CRC employees might influence their SOC;

$\mathrm{H}_{2-2}$ : Job position of CRC employees might influence their SOC; and $\mathrm{H}_{2-3}$ : Job tenure of CRC employees might influence their SOC.

H3: The CRC employees' job satisfaction levels might vary in relation to their demographic information, including gender, job position, and job tenure.

$\mathrm{H}_{3-1}$ : Gender of CRC employees might influence their job satisfaction; $\mathrm{H}_{3-2}$ : Job position of CRC employees might influence their job satisfaction; $\mathrm{H}_{3-3}$ : Job tenure of CRC employees might influence their job satisfaction. 


\section{CHAPTER III: METHODOLOGY}

This study examines whether there is a relationship between SOC and job satisfaction among the employees working at CRCs. Also, this study aims to investigate if the demographic factors (e.g., gender, job position, and jot tenure) influence the degree to which SOC or job satisfaction the employees in CRCs experience. A cross-sectional research design using a questionnaire (Jones, 2015) was used. To measure employees' SOC, Sense of Community Index 2 developed by Chavis and colleagues (2008) was adopted. Also, employees' job satisfaction was measured by Spector's (1985) JSS. The details of the methods used in this study are presented in the following sections: (a) Participants; (b) Instrumentation; (c) Sampling method; (d) Data Collection; and (d) Data Analysis.

\section{Participants}

The setting for the current research was the five CRCs in the universities. The universities, which located in the United States, offer a variety of programs for collegiate students. Based on the number of enrolled student population and programs and size of school, CRC has a different number of employees: student employees, graduate assistants, part-time employees, and full-time employees. One of CRCs has about 50 number of part-time and fulltime employees and about 600 number of student employees and graduate assistants. On the other hand, CRC having the least employees, has around 20 full-time and part-time employees and graduate assistants and around 100 student employees.

As indicated above, the participants identified in the study were the set of student employees, graduate assistants, part-time employees, and full-time employees who work at CRCs of five universities. A total of about 1,136 participants were emailed and asked to participate in the online survey by managers in each CRC. Of that number, 150 employees 
participated in the survey. As a result, the total response rate that $\mathrm{CRC}$ employees participate in this survey is $13 \%$. The response rate appears low, but Schonlau, Fricker \& Elliott (2001) indicated that response rates for Web-based surveys are low as seven percent and six percent for email surveys in the research. It was supported that the surveys based on online or Internet have lower response rates compared to the surveys based on mail or phone (Northey, 2005).

\section{Instrumentation}

As shown in Appendix A, the questionnaire is composed of three parts: job satisfaction, sense of community, and demographics questions.

\section{Job Satisfaction Survey (JSS)}

In the first portion of the questionnaire, the Job Satisfaction Survey (JSS) created by Spector (1985) assessed job satisfaction of employees. The JSS suggests a total job satisfaction score based on the measurement of nine separate aspects of job satisfaction: (a) pay, (b) promotion, (c) supervision, (d) fringe benefits, (e) contingent rewards, (f) operating conditions, (g) coworkers, (h) nature of work, and (i) communication. The complete list of constructs and corresponding items are listed in Table 1. Each item uses a six-point Likert response scale ranging from $1=$ disagree very much to $6=$ agree very much. Spector (1985) evaluated the validity and internal consistency based on alpha coefficients through a sample of 2,870 . The total alpha coefficients for JSS is .91. The JSS has been utilized to examine the extent which employees are satisfied with their jobs in diverse fields, such as campus recreation, education, and sports (Kaltenbaugh, 2009; Hariri, Monypenny, \& Prideaux, 2012; Parsons, Kaltenbaugh, Brubaker, Winters, \& Cali, 2013). 
Table 1. Subscale Contents for the Job Satisfaction Survey

\begin{tabular}{ll}
\hline Subscale & Item Number \\
\hline Pay & $1,10 \mathrm{r}, 19 \mathrm{r}, 28$ \\
Promotion & $2 \mathrm{r}, 11,20,33$ \\
Supervision & $3,12 \mathrm{r}, 21 \mathrm{r}, 30$ \\
Fringe benefits & $4 \mathrm{r}, 13,22,29 \mathrm{r}$ \\
Contingent rewards & $5,14 \mathrm{r}, 23 \mathrm{r}, 32 \mathrm{r}$ \\
Operating conditions & $6 \mathrm{r}, 15,24 \mathrm{r}, 31 \mathrm{r}$ \\
Coworkers & $7,16 \mathrm{r}, 25,34 \mathrm{r}$ \\
Nature of work & $8 \mathrm{r}, 17,27,35$ \\
Communication & $9,18 \mathrm{r}, 26 \mathrm{r}, 36 \mathrm{r}$ \\
\hline
\end{tabular}

Note: Items followed by " $r$ " should be reverse-scored. Reprinted from "Measurement of Human Service Staff Satisfaction: Development of the Job Satisfaction Survey," by Spector, P., 1985, American Journal of Community Psychology, 13(6), 693-713.

\section{Sense of Community Index 2 (SCI-2)}

To examine employee SOC, the Sense of Community Index 2 (SCI-2) created by Chavis, Lee, and Acosta (2008) was utilized for the questionnaire. Chavis and colleagues (2008) developed SCI-2 to overcome inconsistent reliability and limited validity of the Sense of Community Index (SCI) (Chavis, Hogge, McMillan, \& Wandersman, 1986). The SCI-2 consists of subscales based on McMillan and Chavis' (1986) SOC theory, composed of four elements: membership, influence, integration and fulfillment of needs, and a shared emotional connection to recognize SOC. The SCI-2 involves 25 questions, including a question that assesses the participants' perception of the importance of SOC with a six-point Likert response scale. As shown in Table 2, the following 24 questions are rated based on a four-point Likert response scale ranging from $0=$ not at all to $3=$ completely. The reliability of SCI- 2 was assessed by Chavis and colleagues (2008) based on a survey of 1,800 participants with a coefficient alpha of .94. Previous research also has utilized the SCI-2 to study SOC in different settings, such as sports and education (Warner \& Leierer, 2015; Foli, Karagory, Gibson, \& Kirkpatrick, 2013). 
Table 2. Subscale and items for Sense of Community Index 2

\begin{tabular}{ll}
\hline Subscale & Item number \\
\hline Membership & Q7, Q8, Q9, Q10, Q11, Q12 \\
Influence & Q13, Q14, Q15, Q16, Q17, Q18 \\
Reinforcement of Needs & Q1, Q2, Q3, Q4, Q5, Q6 \\
Share Emotional Connection & Q19, Q20, Q21, Q22, Q23, Q24 \\
\hline
\end{tabular}

Note: Reprinted from "Sense of Community Index 2 (SCI-2): Background, instrument, and scoring instructions," by Chavis, D. M., Lee, K. S., \& Acosta, J. D. (2008). Retrieved from http://dl.icdst.org/pdfs/files/f458fof15016819295377e5a979b1893.pdf

\section{Demographics Questions}

In the last portion of the questionnaire, the participants were asked questions about their demographic information, including gender, job position, and job tenure. First, gender was posed as a question with three options for male, female, and non-binary. Job position was also asked with four possible selections, including student employee, graduate assistant, part-time employee, and full-time employee. Lastly, participants were asked of job tenure, which refers to how long the participants have been working at CRCs with the four options, involving less than 1 year, from $1-4$ years, from $5-7$ years, and above 7 years. The variables were collected to not only describe the participants of this study but also determine if these influence the degree to which SOC or job satisfaction the employees experience.

\section{Qualtrics $^{\mathrm{XM}}$}

This study utilized the online survey platform Qualtrics to collect the data. Qualtrics is one of the more popular online survey platforms. With regard to the advantages of an online survey, Blasius and Brandt (2010) pointed out that online surveys have low or no cost, better response rates, and need less time to complete.

\section{Sampling Methods}

This study adopted two sampling methods, that of snowball sampling and convenience sampling. Snowball sampling is a non-probability sampling technique where initial participants 
can introduce further potential participants (Jones, 2015). Jones (2015) described convenience sampling as a sampling technique where the researcher chooses samples based on location and accessibility, which is a convenient approach. Snowball sampling technique was utilized for the first step of the study, where the researcher contacted initial participants who are managers at CRCs. Through this step, the researcher identified if the managers in CRCs want to participate in this study with their employees. Once the researcher received the replies from the managers in CRCs, participants who work at CRCs were gathered based on convenience sampling.

\section{Data Collection}

Prior to the data collection procedure, this study was approved by the Institutional Review Board (IRB) of Illinois State University (protocol \#2019761). Once the instruments and consent form for the study was approved, data collection began.

Through snowball sampling, the managers of CRCs in several universities were selected and were contacted by the researcher. The managers were delivered of the information of the survey, including the purpose of this study and anonymity of the participants, and asked for the willingness to attend the survey. Once the managers approved and sent site permission letters to the researcher, the researcher provided information on the survey and survey link to the managers via email. The survey link was designed for participants to answer the consent form at first and move into the questions of the survey. The managers sent the email attached to the survey information to the employees. The reminder emails were sent to participants two times. A week after the initial email sent, the managers in CRCs sent the first reminder email. The second reminder email was sent two weeks after the first reminder email was delivered. The data collection of this study began in January and concluded in March of 2020. 


\section{Data Analysis}

Data were managed and analyzed using IBM's Statistical Package for (SPSS) version 24.0. The initial descriptive analyses, Pearson Correlation Coefficient, independent sample Ttest, and one-way MANOVA were performed to test hypotheses.

First of all, the initial descriptive analyses were utilized to examine not only overall job satisfaction and SOC but also the degree which to participants experience in each subset of job satisfaction and SOC. The relationship between the total of job satisfaction and the total of SOC was analyzed using Pearson Correlation Coefficient, a statistical analysis used to assess the correlation between two variables. Also, the impact of participants' demographic information on their level of job satisfaction and SOC was assessed using independent sample t-test. The independent variable was participants' demographic information at two levels (i.e., gender: female and male, job position: student employees and professional employees, job tenure: less than 1 year and above 1 year). The dependent variables were job satisfaction and SOC.

Also, one-way MANOVA was performed to measure if there is a difference between participants' demographic information and each subset of SOC and job satisfaction that participants feel. The independent variable was demographic information, which indicated above. The dependent variables were the four subsets of SOC (e.g., reinforcement of needs, membership, influence, and shared emotional connection) and nine subset of job satisfaction (e.g., pay, promotion, supervision, benefits, contingent rewards, operating procedures, coworkers, nature of work, and communication). 


\section{CHAPTER IV: RESULTS}

This study aimed to examine the relationship between SOC and job satisfaction of the employees at CRCs. Furthermore, it investigates if participants' demographic information (e.g. gender, job position, and job tenure) influences on the extent to which participants feel SOC or job satisfaction. Data was collected and analyzed from January to March of 2020.

\section{Sample Size and Data Screening}

A total of 150 survey responses were collected, resulting in a $13 \%$ response rate. However, in the process of data screening, 58 surveys, which respondents did not finish, were detected and were removed since it deemed unusable for the objective of this study. Also, five outliers were detected and discarded through boxplots. Therefore, 87 surveys were used for analysis in this study.

As illustrated in Table 3, the subjects of this study are composed of 60 females, 25 males, and two non-binary, who work at CRCs. The employees were asked to indicate their job position. The subjects consist of 65 student employees, four graduate assistants, three part-time employees, and 15 full-time employees. In addition to the job position, the subjects were also asked to indicate job tenure. The subjects were 38 employees working for less than 1 year, 39 employees from 1 to 4 years, six employees from 5 to 7 years, and four employees above 7 years.

According to Krithikadatta (2014), sample size significantly influences on the normality of data distribution, so normality of data distribution should be supported through adequacy of sample size. In order to ensure robustness of data analysis, the subjects with different demographic factors were combined. As shown in Table 3, two subjects identifying their gender as non-binary were removed. For variable "Gender", 60 females and 25 males were analyzed 
because of the low number of subjects in the non-binary group. For variable "Job Position", student employees and graduate assistants were combined as the student employee group, and part-time employees and full-time employees were combined as the professional employee group. For variable "job tenure", data was combined to two groups, less than 1 year and above 1 year due to low number of subjects in the original 4 groups.

Table 3. Sample Demographics

\begin{tabular}{|c|c|c|}
\hline $\begin{array}{l}\text { Demographics } \\
\text { Variables }\end{array}$ & Frequency for original groups & Frequency for combined groups \\
\hline \multirow[t]{3}{*}{ Gender } & Female $=60$ & Female $=60$ \\
\hline & Male $=25$ & Male $=25$ \\
\hline & Non-binary $=2$ & $\begin{array}{l}\text { Non-binary is removed due to } \\
\text { low number of subjects. }\end{array}$ \\
\hline \multirow[t]{5}{*}{ Job position } & Student employee (not including & Student employee group $=69$ \\
\hline & graduate assistant $)=65$ & Professional employee group $=$ \\
\hline & $\begin{array}{l}\text { Student employee (including } \\
\text { graduate assistant) }=4\end{array}$ & 18 \\
\hline & Part-time employee $=3$ & \\
\hline & Full-time employee $=15$ & \\
\hline \multirow[t]{4}{*}{ Job tenure } & Less than 1 year $=38$ & Less than 1 year $=38$ \\
\hline & $1-4$ years $=39$ & Above 1 year $=49$ \\
\hline & $5-7$ years $=6$ & \\
\hline & Above 7 years $=4$ & \\
\hline
\end{tabular}

\section{Descriptive Statistics of SOC and Job Satisfaction}

Descriptive statistics were analyzed to examine CRC employees' levels of SOC and job satisfaction. Respondents were asked to answer the questions related to the four sub facets of SOC and nine sub facets of the Job Satisfaction Survey. The four sub facets of SOC included reinforcement of needs, membership, influence, and shared emotional connection. The Job Satisfaction Survey involved nine sub facets, including pay, promotional opportunities, fringe benefits, contingent rewards, supervision, co-workers, nature of work, communication, and work conditions. 
As indicated in Table 4, results show that participants feel SOC when the mean scores were above the midpoint (1.5) of the scale and do not feel SOC when below. The highest mean score was reinforcement of needs $(M=1.88)$ whereas the lowest mean score was shared emotional connection $(M=1.66)$. The mean score of total SOC was 1.73 . Overall, the results showed that participants felt SOC (above 1.5) in membership, influence, and shared emotional connection, reinforcement of needs, where the employees in CRCs scored above the mean of the scale.

Table 4. Descriptive Statistics of SOC of the employees in CRCs

\begin{tabular}{lccc}
\hline \multicolumn{1}{c}{ SOC dimensions } & $M$ & $S D$ & Range \\
\hline Reinforcement of needs & 1.88 & .57 & 2.33 \\
Membership & 1.67 & .64 & 2.83 \\
Influence & 1.71 & .57 & 2.33 \\
Shared Emotional Connection & 1.66 & .66 & 3.00 \\
$\quad$ Total SOC & 1.73 & .56 & 2.38 \\
\hline
\end{tabular}

In table 5, results indicate the extent to which participants are satisfied with their job in CRCs. The results show if the participants feel the satisfaction of their jobs in CRCs based on the midpoint (3.5) of the scale. The highest mean score was supervision $(M=5.29)$, and the lowest mean score was pay $(M=3.56)$. The mean score of total job satisfaction was 4.33 . The results showed that participants were satisfied (above 3.5) with all of the nine sub facets: pay, promotion, supervision, fringe benefits, contingent rewards, operating conditions, coworkers, nature of work, and communication. 
Table 5. Descriptive Statistics of Job Satisfaction of the employees in CRCs

\begin{tabular}{lccc}
\hline $\begin{array}{c}\text { Job Satisfaction Survey } \\
\text { dimensions }\end{array}$ & $M$ & $S D$ & Range \\
\hline Pay & 3.56 & 1.06 & 5.00 \\
Promotion & 3.83 & .95 & 4.50 \\
Supervision & 5.29 & .78 & 2.75 \\
Fringe benefits & 3.79 & 1.05 & 5.00 \\
Contingent rewards & 4.10 & 1.03 & 5.00 \\
Operating conditions & 4.17 & .90 & 4.75 \\
Coworkers & 5.08 & .78 & 3.25 \\
Nature of work & 4.68 & .94 & 4.25 \\
Communication & 4.45 & .95 & 4.25 \\
$\quad$ Total satisfaction & 4.33 & .61 & 2.97 \\
\hline
\end{tabular}

\section{Hypothesis 1}

Pearson correlation coefficient was conducted to identify if there is a relationship between SOC and job satisfaction that CRC employees feel. As indicated in Table 6, the results suggested that there was a moderate positive correlation between the employees' SOC and job satisfaction $(r(85)=.385, p<.001)$.

Table 6. Pearson Correlation Coefficient of SOC and job satisfaction

\begin{tabular}{lcc}
\hline & Job Satisfaction & SOC \\
\hline 1. Job satisfaction Total & -- & $.385^{* *}$ \\
2. SOC Total & $.385^{* *}$ & -- \\
\hline$* *$ Correlation is significant at the .01 level (2-tailed) &
\end{tabular}

\section{Hypothesis 2}

\section{Gender and CRC Employees' SOC $\left(\mathrm{H}_{2-1}\right)$}

The data were normally distributed based on the assessment of Levene's Test $(p>.05)$.

As illustrated in Table 7, there were no significant differences in SOC levels between female and male employees in CRCs $(t(83)=.004, p>.05)$. The mean of the female employees' SOC $(M=$ 41.27, $S D=14.28$ ) was not significantly different from the mean of the male employees' SOC $(M=41.28, S D=12.16)$. 
A multivariate analysis of variance (MANOVA) was performed based on the two groups: male and female as the independent variable and the four subsets of SOC: reinforcement of needs, membership, influence, and shared emotional connection as the dependent variables. A one-way MANOVA was calculated to test if employees' SOC in the four subsets was significantly different between males and females. The Box's test was conducted to examine the equality of covariance between the groups. The result indicated the equal variances (Box's $\mathrm{M}=$ 9.84, $p>.001)$. As Table 8. showed, Wilks' Lambda was utilized, and there was no significant difference in the four subsets of SOC based on their gender, $F(4,80)=.926, p>.05$; Wilk's $\Lambda$ $=.956$, partial $\eta^{2}=.044$. The level of each subset of CRC employees' SOC was not significantly influenced by their gender.

Table 7. Independent Sample t-test of gender and SOC

\begin{tabular}{ccccccccc}
\hline & Gender & $N$ & $M$ & $S D$ & $S E M$ & $t$ & $d f$ & $p$ \\
\hline Total of & Male & 25 & 41.28 & 12.16 & 2.43 & .004 & 83 & .997 \\
SOC & Female & 60 & 41.27 & 14.28 & 1.84 & & & \\
\hline
\end{tabular}

Table 8. Multivariate Tests of gender and SOC

\begin{tabular}{lcccccc}
\hline & Value & $F$ & Hypothesis df & Error df & Sig. & $\begin{array}{c}\text { Partial } \\
\text { Eta } \\
\text { Squared }\end{array}$ \\
\hline Pillai's Trace & .044 & .926 & 4.000 & 80.000 & .453 & .044 \\
Wilks' Lambda & .956 & .926 & 4.000 & 80.000 & .453 & .044 \\
Hotelling's Trace & .046 & .926 & 4.000 & 80.000 & .453 & .044 \\
Roy's Largest Root & .046 & .926 & 4.000 & 80.000 & .453 & .044 \\
\hline
\end{tabular}

\section{Job Position and CRC Employees' SOC $\left(\mathrm{H}_{2-2}\right)$}

The data were normally distributed by the assessment of Levene's Test $(p>.05)$. As showed in Table 9, the result illustrate that there were no significant differences in the level of SOC between student employees and professional employees in CRCs $(t(85)=.64, p>.05)$. The mean of the student employees' SOC $(M=41.96, S D=14.21)$ was not significantly different with the mean of professional employees' SOC $(M=39.67, S D=10.83)$. 
A one-way MANOVA was calculated examining the effect of job positions on the four subsets of SOC that employees in CRCs feel. The Box's test was performed to examine the equality of covariance between the groups. The result indicated the equal variances (Box's $\mathrm{M}=$ 19.64, $p>.001)$. As Table 10 illustrated, Wilks’ Lambda was utilized and there were no significant difference in CRC employees' SOC based on their job position, $F(4,82)=.818, p$ $>.05$; Wilk's $\Lambda=.962$, partial $\eta^{2}=.038$. The level of each subset of CRC employees' SOC was not significantly influenced by their job position.

Table 9. Independent Sample t-test of job position and SOC

\begin{tabular}{clccccccc}
\hline \multicolumn{2}{c}{ Job position } & $N$ & $M$ & $S D$ & $S E M$ & $t$ & $d f$ & $p$ \\
\hline Total of & $\begin{array}{l}\text { Student } \\
\text { employee }\end{array}$ & 69 & 41.96 & 14.21 & 1.71 & .636 & 85 & .53 \\
SOC & $\begin{array}{l}\text { Professional } \\
\text { employee }\end{array}$ & 18 & 39.67 & 10.83 & 2.55 & & & \\
\hline
\end{tabular}

Table 10. Multivariate Tests of job position and SOC

\begin{tabular}{lcccccc}
\hline & Value & $F$ & Hypothesis & Error df & Sig. & ${\text { Partial } \eta^{2}}$ \\
\hline Pillai's Trace & .038 & .818 & 4.000 & 82.000 & .517 & .038 \\
Wilks' Lambda & .962 & .818 & 4.000 & 82.000 & .517 & .038 \\
Hotelling's Trace & .040 & .818 & 4.000 & 82.000 & .517 & .038 \\
Roy's Largest Root & .040 & .818 & 4.000 & 82.000 & .517 & .038 \\
\hline
\end{tabular}

\section{Job Tenure and CRC Employees' SOC $\left(\mathrm{H}_{2-3}\right)$}

The data were normally distributed by assessment of Levene's Test $(p>.05)$. In Table 11, there were no significant differences in the level of SOC between CRC employees who work less than 1 year and above 1 year $(t(85)=1.01, p>.05)$. The mean of the employees' SOC who work less than 1 year $(M=43.16, S D=12.65)$ was not significantly different from the mean of the employees' SOC who work above 1 year $(M=40.18, S D=14.21)$.

A one-way MANOVA was performed to investigate if job tenure effects on the four subsets of SOC that employees experience. The Box's test was conducted to examine the equality of covariance between the groups. The result indicated the equal variances (Box's $\mathrm{M}=$ 
$8.74, p>.001)$. As Table 12 showed, Wilks' Lambda was utilized and there was no significant difference in the four subsets of SOC based on job tenure, $F(4,82)=.687, p>.05$; Wilk's $\Lambda$ $=.968$, partial $\eta 2=.032$.

Table 11. Independent Sample t-test of job tenure and SOC

\begin{tabular}{ccccccccc}
\hline & Job tenure & $N$ & $M$ & $S D$ & $S E M$ & $t$ & $d f$ & $p$ \\
\hline \multirow{2}{*}{$\begin{array}{c}\text { Total of } \\
\text { SOC }\end{array}$} & $\begin{array}{c}\text { year } \\
>1\end{array}$ & 38 & 43.16 & 12.65 & 2.05 & 1.01 & 85 & .31 \\
& $\begin{array}{c}\text { year } \\
\text { year }\end{array}$ & 49 & 40.18 & 14.21 & 2.03 & & & \\
\hline
\end{tabular}

Table 12. Multivariate Tests of job tenure and SOC

\begin{tabular}{lcccccc}
\hline & Value & $F$ & Hypothesis $d f$ & Error $d f$ & Sig. & Partial $^{2}$ \\
\hline Pillai's Trace & .032 & .687 & 4.000 & 82.000 & .603 & .032 \\
Wilks' Lambda & .968 & .687 & 4.000 & 82.000 & .603 & .032 \\
Hotelling's Trace & .034 & .687 & 4.000 & 82.000 & .603 & .032 \\
Roy's Largest Root & .034 & .687 & 4.000 & 82.000 & .603 & .032 \\
\hline
\end{tabular}

\section{Hypothesis 3}

\section{Gender and CRC Employees' Job Satisfaction $\left(\mathrm{H}_{3-1}\right)$}

As assessed by Levene's Test $(p>.05)$, the data were normally distributed. In the Table 13 , the result of independent sample t-test indicated that there were no significant differences in the level of job satisfaction between female and male employees in CRCs $(t(83)=-1.21, p$ $>.05)$. The mean of the female employees' job satisfaction $(M=157.43, S D=22.97)$ was not significantly different from the mean of the male employees' job satisfaction $(M=151.04, S D=$ 20.35).

A one-way MANOVA was calculated to investigate the effect of job gender: male and female, which is the independent variable, on nine subsets of job satisfaction: pay, promotional opportunities, fringe benefits, contingent rewards, supervision, co-workers, nature of work, communication, and work conditions, which are the dependent variables. The Box's test was conducted to examine the equality of covariance between the groups. The result indicated the 
equal variances (Box's $M=65.29, p>.001)$. As Table 14 showed, Wilks' Lambda was utilized and there was no significant difference in the nine subsets of job satisfaction based on their gender, $F(9,75)=.1 .768, p>.05 ;$ Wilk's $\Lambda=.825$, partial $\eta 2=.175$. The level of each subset of CRC employees' job satisfaction was not significantly influenced by their gender.

Table 13. Independent Sample t-test of gender and Job satisfaction

\begin{tabular}{ccccccccc}
\hline & Gender & $N$ & $M$ & $S D$ & $S E M$ & $t$ & $d f$ & $p$ \\
\hline Total of & Male & 25 & 151.04 & 20.35 & 4.07 & -1.21 & 83 & .231 \\
Job & Female & 60 & 157.43 & 22.97 & 2.97 & & & \\
Satisfaction & & & & & & & & \\
\hline
\end{tabular}

Table 14. Multivariate Tests of gender and Job satisfaction

\begin{tabular}{lcccccc}
\hline & Value & $F$ & Hypothesis $d f$ & Error df & Sig. & Partial $^{2}$ \\
\hline Pillai's Trace & .175 & 1.768 & 9.000 & 75.000 & .089 & .175 \\
Wilks' Lambda & .825 & 1.768 & 9.000 & 75.000 & .089 & .175 \\
Hotelling's Trace & .212 & 1.768 & 9.000 & 75.000 & .089 & .175 \\
Roy's Largest Root & .212 & 1.768 & 9.000 & 75.000 & .089 & .175 \\
\hline
\end{tabular}

\section{Job Position and CRC Employees' Job Satisfaction $\left(\mathrm{H}_{3-2}\right)$}

The data were normally distributed by assessment of Levene's Test $(p>.05)$. As illustrated in Table 15, there were no significant differences in job satisfaction levels between student employees and professional employees in $\operatorname{CRCs}(\mathrm{t}(85)=1.10, \mathrm{p}>.05)$. The mean of job satisfaction in the student employees $(M=157.07, S D=22.74)$ was not significantly different from the mean of job satisfaction in the professional employees $(M=150.67, S D=19.05)$.

A one-way MANOVA was performed to investigate the effect of job position: student employees and professional employees on nine subsets of job satisfaction. The Box's test was calculated to examine the equality of covariance between the groups. The result showed the equal variances (Box's $\mathrm{M}=67.77, p>.001$ ). As Table 16 illustrated, Wilks' Lambda was utilized, and there was significant difference in the nine subsets of job satisfaction based on job position, $F(9,77)=7.807, p<.05$; Wilk's $\Lambda=.523$, partial $\eta 2=.477$. As shown in Table 17 , the results showed that the mean scores of three subsets in job satisfaction: fringe benefits $(F(1,85)=$ 
$6.875, p=.010)$, operating conditions $(F(1,85)=17.854, p=.00)$, coworkers $(F(1,85)=7.215, p$ $=.009$ ) were statistically significantly different based on the employees' job positions. To be specific, the professional employee group $(M=4.35)$ was more satisfied with fringe benefits than the student employee group $(M=3.64)$. On the other hand, the student employee group $(M=$ 4.36) experienced higher job satisfaction in operating conditions compared to the professional employee group $(M=3.44)$. Also, the student employee group $(M=5.18)$ was more satisfied with coworkers than the professional employee group $(M=4.65)$.

Table 15. Independent Sample t-test of job position and Job satisfaction

\begin{tabular}{ccccccccc}
\hline & Job position & $N$ & $M$ & $S D$ & $S E M$ & $t$ & $d f$ & $p$ \\
\hline $\begin{array}{c}\text { Total of } \\
\text { Job }\end{array}$ & $\begin{array}{c}\text { Student } \\
\text { employees }\end{array}$ & 69 & 157.07 & 22.74 & 2.74 & 1.10 & 85 & .28 \\
Satisfaction & $\begin{array}{c}\text { Professional } \\
\text { employees }\end{array}$ & 18 & 150.67 & 19.05 & 4.49 & & & \\
\hline
\end{tabular}


Table 16. Multivariate Tests of job position and Job satisfaction

\begin{tabular}{lcccccc}
\hline & Value & $F$ & Hypothesis $d f$ & Error $d f$ & Sig. & ${\text { Partial } \eta^{2}}$ \\
\hline Pillai's Trace & .477 & 7.807 & 9.000 & 77.000 & .000 & .477 \\
Wilks' Lambda & .523 & 7.807 & 9.000 & 77.000 & .000 & .477 \\
Hotelling's Trace & .912 & 7.807 & 9.000 & 77.000 & .000 & .477 \\
Roy's Largest Root & .912 & 7.807 & 9.000 & 77.000 & .000 & .477 \\
\hline
\end{tabular}

Table 17. Tests of Between-Subjects Effects of job position and nine subsets of job satisfaction

\begin{tabular}{|c|c|c|c|c|c|c|c|}
\hline & $D V$ & $\begin{array}{l}\text { Type III } \\
\text { Sum of } \\
\text { Squares }\end{array}$ & $d f$ & $\begin{array}{c}\text { Mean } \\
\text { Square }\end{array}$ & $F$ & Sig. & $\begin{array}{c}\text { Partial } \\
\eta^{2}\end{array}$ \\
\hline Job & Pay & 2.146 & 1 & 2.146 & 1.916 & .170 & .022 \\
\hline \multirow[t]{8}{*}{ position } & Promotion & 2.736 & 1 & 2.736 & 3.134 & .080 & .036 \\
\hline & Supervision & .053 & 1 & .053 & .087 & .768 & .001 \\
\hline & Fringe benefits & 7.114 & 1 & 7.114 & 6.875 & .010 & .075 \\
\hline & Contingent rewards & .000 & 1 & .000 & .000 & .988 & .000 \\
\hline & Operating conditions & 12.027 & 1 & 12.027 & 17.854 & .000 & .174 \\
\hline & Coworkers & 4.040 & 1 & 4.040 & 7.215 & .009 & .078 \\
\hline & Nature of Work & 3.047 & 1 & 3.047 & 3.543 & .063 & .040 \\
\hline & Communication & 2.624 & 1 & 2.624 & 2.950 & .090 & .034 \\
\hline
\end{tabular}

\section{Job Tenure and CRC Employees' Job Satisfaction $\left(\mathrm{H}_{3-3}\right)$}

The data were normally distributed by assessment of Levene's Test $(p>.05)$. In Table 18 , the result showed that there were no significant differences in job satisfaction levels between CRC employees who work less than 1 year and above 1 year $(t(85)=1.75, p>.05)$. The mean of job satisfaction in the employees who work less than 1 year $(M=160.39, S D=23.66)$ was not significantly different from the mean of job satisfaction in the employees who work above 1 year $(M=152.14, S D=20.29)$.

A one-way MANOVA was performed to investigate the effect of job tenure: less than 1 year and above 1 year on nine subsets of job satisfaction. The Box's test was conducted to examine the equality of covariance between the groups. The result indicated the equal variances (Box's $\mathrm{M}=80.46, p>.001$ ). As Table 19 showed, Wilks' Lambda was utilized, and there was no significant difference in the nine subsets of job satisfaction based on job tenure, $F(9,77)$ 
$=.1 .896, p>.05 ;$ Wilk's $\Lambda=.819$, partial $\eta^{2}=.181$. The level of each subset of CRC employees' job satisfaction was not significantly influenced by their job tenure.

Table 18. Independent Sample t-test of job tenure and Job satisfaction

\begin{tabular}{lcccccccc}
\hline & Job tenure & $N$ & $M$ & $S D$ & $S E M$ & $t$ & $d f$ & $p$ \\
\hline Total of Job & $\leq 1$ year & 38 & 160.39 & 23.66 & 3.84 & 1.75 & 85 & .08 \\
Satisfaction & $>1$ year & 49 & 152.14 & 20.29 & 2.90 & & & \\
\hline
\end{tabular}

Table 19. Multivariate Tests of job tenure and Job satisfaction

\begin{tabular}{lcccccc}
\hline & Value & $F$ & Hypothesis $d f$ & Error $d f$ & Sig. & Partial $^{2}$ \\
\hline Pillai's Trace & .181 & 1.896 & 9.000 & 77.000 & .065 & .181 \\
Wilks' Lambda & .819 & 1.896 & 9.000 & 77.000 & .065 & .181 \\
Hotelling's Trace & .222 & 1.896 & 9.000 & 77.000 & .065 & .181 \\
Roy's Largest Root & .222 & 1.896 & 9.000 & 77.000 & .065 & .181 \\
\hline
\end{tabular}




\section{CHAPTER V: DISCUSSION}

The current study examines the extent to which employees in CRCs feel SOC and job satisfaction. The findings show that the four mean scores for the sub-facets of SOC (e.g., reinforcement of needs, membership, influence, and shared emotional connection) were above the midpoint of the scale, and reinforcement of needs were above the mean scores of the total of SOC. On the other hand, the findings show that the nine mean scores in the sub-facets of job satisfaction (e.g., pay, promotional opportunities, fringe benefits, contingent rewards, supervision, coworkers, nature of work, communication, and work conditions) were above the midpoint of the scale. As Kaltenbaugh (2009) revealed that campus recreation professionals found value in supervision and coworkers, this study also found that the employees in CRCs regard supervision, coworkers, nature of work, and communication as essential components for their job satisfaction.

\section{The Relationship Between SOC and Job Satisfaction of CRC Employees}

Hypothesis 1 investigates if there is a correlation between SOC and job satisfaction that employees in CRCs experience. This study found that if employees in CRCs experience a high level of SOC, they are more satisfied with their job regardless of their gender, job position, and job tenure through comparison of total values of SOC and job satisfaction. This finding is similar to those from different contexts, such as the educational setting (Royal \& Rossi, 1996; McGinty, Justice, \& Rimm-Kaufman, 2008). On the other hand, Klein \& D’Aunno (1986) stated it is not necessary for the employees to be satisfied with their jobs to experience SOC at work if the employees work under certain working condition, where they would be evaluated based on individual work. Given the current research, it may be assumed that CRC is a workplace that is 
based on teamwork, and CRC employees experience satisfaction with their job as they work with coworkers.

\section{The Influence of Demographic Information on CRC Employees' levels of SOC}

The finding shows that gender did not influence the degree to which SOC affects employee experience in CRCs. Even though there were slight differences in mean scores of two facets of SOC, that of influence and shared emotional connection, among male and female employees, the results were not statistically significant. In addition, significant differences were not found in comparing the total scores of SOC based on gender. This research finding is not aligned with the literature, however, which shows that female participants feel higher SOC compared to male participants in education (Rovai, 2002), but implies that male and female employees in CRCs experience similar level of SOC.

This study also examines if job positions influence the extent to which employees feel SOC. Findings show that job position did not have an influence on SOC that CRC employees experienced, but there were subtle differences in three subsets in SOC: reinforcement of needs, influence, and shared emotional connection. The results were not statistically significant, however. Also, the comparison of job position and the total scores of SOC did not show significant differences. This finding is consistent with the research of Royal and Rossi (1996), who found that employees' tenure or job position is not related to SOC in the education setting. The finding of the current study implies that employees in CRCs experience a similar degree of SOC regardless of their job positions.

With gender and job position, job tenure in this study was considered as a variable that might influence employees' SOC, since time is an important source for individuals to not only be integrated into the community but also feel SOC (Royal \& Rossi, 1996). Klein and D’Aunno 
(1986) suggested that employees who worked longer in the workplace feel a greater SOC than employees with less tenure. However, the finding of this study reveals that job tenure did not have an influence on SOC that CRC employees experienced. There were slight differences in mean scores in all four subsets of SOC (e.g., reinforcement of needs, membership, influence, and shared emotional connection) between employees working less than 1 year and more than 1 year, but the result was not statistically significant. Furthermore, the comparison of the total of SOC based on job tenure did not show significant differences.

\section{The influence of Demographic Information on CRC Employees' levels of Job Satisfaction}

Azhar and Asdaque (2011) found some differences in the level of job satisfaction between male and female employees in the education context. However, the finding of the current research shows that gender did not influence the degree of job satisfaction employees in CRCs feel. Even though there were slight differences in mean scores of two subscales of job satisfaction, including the operating conditions and coworkers among male and female employees, these were not statistically significant. Also, significant differences were not found in the comparison of the total job satisfaction scores based on gender.

Although gender did not have a significant impact on job satisfaction in this study, job position might show some impact on job satisfaction. According to Stier and the colleagues' study (2010), employees in higher positions feel a higher level of job satisfaction compared to lower positions in a campus recreation setting. A similar finding was supported in the research of Ross, Young, Sturts, and Kim (2014). Findings of the current study were partially consistent in that, employees in a higher position in CRCs were more satisfied with their job compared to employees with lower positions. To be specific, the finding revealed that there were no significant differences in the total of job satisfaction scores between student employees and 
professional employees. However, when MANOVA was performed to compare each of the nine subsets in job satisfaction to job positions, the finding show significant differences in fringe benefits, operating conditions, and coworkers. This finding implies that professional employees experience a higher level of job satisfaction when they have additional benefits, such as an office, and student employees feel higher job satisfaction with rules, procedures, and coworkers. This is a valuable finding in showing that employees with different positions experience job satisfaction in different elements of CRCs, which will help practitioners consider the ways to enhance the degree of job satisfaction employees in CRCs experience related to their job positions.

Another factor that this study looks at is the job tenure. According to the literature, the job satisfaction of the employees could be predicted based on the period of their job service (Sarker, Crossman, \& Chinmeteepituck, 2003). In the previous research, it was found that job tenure positively influences employees' job satisfaction in the campus recreational sports context (Ross et al., 2014; Zhang, Demichele, \& Connaughton, 2004). However, the finding of this study did not show that job tenure influences job satisfaction of CRC employees who work less than 1 year and more than 1 year.

\section{Limitations}

Several limitations were found throughout the process of interpreting the results of this study. First of all, findings of the current study may not be generalized to all employees working in CRC settings due to the demographics of the sample population. Several CRCs in the universities located in some states in the United States joined this study, but they are not representative of CRCs in universities as a whole, nor the population of employees in CRCs. The findings, therefore, may not be generalized to other CRCs. 
Second, one of the instruments adopted by this study had not been tested in the CRC context. This study utilizes two instruments to measure SOC and job satisfaction, including Spector's (1985) JSS and Chavis, Lee, \& Acosta's (2008) SCI-2. In the study of Kaltenbaugh (2009), Spector's (1985) JSS was tested to measure job satisfaction of employees in CRCs. On the other hand, Chavis, Lee, \& Acosta's (2008) SCI-2 was utilized to measure SOC in education and sports (Warner \& Leierer, 2015; Foli et al., 2013), but not in the campus recreation center context. This may generate validity concerns when future researchers conduct research in a similar context. Further investigation may need to apply SCI-2 created by Chavis, Lee, \& Acosta (2008).

Third, the online survey method and long questionnaire used in this study led to a lack of data. Nulty (2008) showed that online survey has markedly lower response rates than paper surveys, and the longer questionnaire also influences a participant's willingness to complete the survey. This led to a low response rate overall with 58 incomplete responses out of 150 in the study. The results thus need to be interpreted with caution because of the small sample size

\section{Implications and Recommendations}

From the theoretical perspective, the study contributes by extending not only the field of study on both SOC and job satisfaction but also the literature on campus recreation context. This study also involves several practical implications in the campus recreation context based on the evidence. First of all, practitioners may consider establishing a strong SOC to increase the employees' job satisfaction and to retain them at CRCs. It may be related to the characteristics of CRC where the employees usually work as a team. Therefore, if practitioners in manager positions provide opportunities that employees participate as a team, it will help the employees experience a higher level of SOC and job satisfaction. 
Also, practitioners are able to consider that professional and student employee groups experience different job satisfaction in fringe benefits, operating conditions, and coworkers. Based on the result, the professional employees were more satisfied with fringe benefits compared to the student employee groups. Comparing to the professional employee groups who entitled more fringe benefits, including office, souvenirs for events, or discounts of the membership, the student employee groups had fewer benefits. It is suggested that providing some fringe benefits to student employee groups may enhance their job satisfaction in this aspect.

Lastly, the finding of this study indicates that the student employees were more satisfied with operating conditions and relationship with coworkers than professional employees. This might be due to the various reason why the student employees decided to work at CRCs in the first place. In the case of the student employee groups, they often start to work at CRC to enhance social skills, gain leadership or accumulate work experiences in the field. Therefore, the specific rules and procedures or coworkers might be important to guide them through their learning process. The practitioners may consider creating checklists of work, manuals, and regular meetings to keep their job satisfaction in operating conditions and coworkers. Future research needs to collect a larger number of participants for robust findings and a better understanding of CRC employee conditions. Also, it is recommended that scholars, and practitioners examine not only SOC and job satisfaction but also other variables, such as job retention and employee burn out.

\section{Conclusions}

The purpose of this study is to identify the relationship between SOC and job satisfaction of CRC employees and the influence of their demographic information on the extent of their 
SOC and job satisfaction. In terms of the relationship between SOC and job satisfaction, the results confirm that SOC influences job satisfaction. On the other hand, significant differences were not found in levels of SOC and job satisfaction based on gender, job position, and job tenure. However, three of nine factors of job satisfaction, including fringe benefits, operating conditions, and coworkers, were significantly different based on job position. In other words, the professional employees were more satisfied with their job based on the benefits received at work, while student employees experienced a higher level of job satisfaction related to work procedures, rules, and coworkers. This study can thus contribute to better understanding of how professionals in CRCs can build strategies to enhance employees' job satisfaction based on their job positions and SOC at work. 


\section{REFERENCES}

Anari, N. N. (2012). Teachers: emotional intelligence, job satisfaction, and organizational commitment. Journal of workplace Learning, 24, 256-269.

Artinger, L., Clapham, L., Hunt, C., Meigs, M., Milord, N., Sampson, B., \& Forrester, S. A. (2006). The social benefits of intramural sports. Naspa Journal, 43(1), 69-86.

Astrauskaite, M., Vaitkevicius, R., \& Perminas, A. (2011). Job satisfaction survey: A confirmatory factor analysis based on secondary school teachers' sample. International Journal of Business and Management, 6(5), 41-50.

Azhar, M., \& Asdaque, M. M. (2011). Job satisfaction of secondary school teachers: A comparative analysis of gender, urban and rural schools. Asian Social Science, 7(8), 203206.

Bamundo, P. J., \& Kopelman, R. E. (1980). The moderating effects of occupation, age, and urbanization on the relationship between job satisfaction and life satisfaction. Journal of Vocational Behavior, 17(1), 106-123.

Belch, H. A., Gebel, M., \& Maas, G. M. (2001). Relationship between student recreation complex use, academic performance, and persistence of first-time freshmen. NASPA Journal, 38(2), 254-268.

Blasius, J., \& Brandt, M. (2010). Representativeness in online surveys through stratified samples. Bulletin of Sociological Methodology/Bulletin de Méthodologie Sociologique, 107(1), 5-21.

Bower, G. G., Hums, M. A., \& Keedy, J. L. (2005). Factors influencing the willingness to mentor students within campus recreation. Recreational Sports Journal, 29(1), 59-77. 
Brackett, M. A., Palomera, R., Mojsa-Kaja, J., Reyes, M. R., \& Salovey, P. (2010). Emotionregulation ability, burnout, and job satisfaction among British secondary-school teachers. Psychology in the Schools, 47(4), 406-417.

Brewer, P., Carnes, L., \& Garner, S. J. (2007). The potential impact of the physical work environment on business teachers' productivity and job satisfaction. Business Education Digest, 16, 29-46.

Brief, A. P., Burke, M. J., George, J. M., Robinson, B. S., \& Webster, J. (1988). Should negative affectivity remain an unmeasured variable in the study of job stress? Journal of Applied Psychology, 73(2), 193-198.

Bryant, J. A., Banta, T. W., \& Bradley, J. L. (1995). Assessment provides insight into the impact and effectiveness of campus recreation programs. NASPA journal, 32(2), 153-160.

Buffum, W. E., \& Konick, A. (1982). Employees' job satisfaction, residents' functioning, and treatment progress in psychiatric institutions. Health \& Social Work, 7(4), 320-327.

Burroughs, S. M., \& Eby, L. T. (1998). Psychological sense of community at work: A measurement system and explanatory framework. Journal of community psychology, 26(6), $509-532$.

Butt, G., \& Lance, A. (2005). Secondary teacher workload and job satisfaction: do successful strategies for change exist? Educational Management Administration \& Leadership, 33(4), 401-422.

Chatman, J. A. (1991). Matching people and organizations: Selection and socialization in public accounting firms. Administrative Science Quarterly, 36, 459-484.

Chavis, D. M., Hogge, J. H., McMillan, D. W., \& Wandersman, A. (1986). Sense of community through Brunswik's lens: A first look. Journal of Community Psychology, 14(1), 24-40. 
Chavis, D. M., Lee, K. S., \& Acosta, J. D. (2008, June). Sense of community index 2 (SCI-2): Background, instrument, and scoring instructions. In second International Conference on Community Psychology, Lisbon.

Chen, J. C., \& Silverthorne, C. (2008). The impact of locus of control on job stress, job performance and job satisfaction in Taiwan. Leadership \& Organization Development Journal, 29(7), 572-582.

Cherniss, C., \& Egnatios, E. (1978). Is there job satisfaction in community mental health?. Community Mental Health Journal, 14(4), 309-318.

Cowin, L. (2002). The effects of nurses' job satisfaction on retention: an Australian perspective. JONA: The Journal of Nursing Administration, 32(5), 283-291.

Cowin, L. S., Johnson, M., Craven, R. G., \& Marsh, H. W. (2008). Causal modeling of selfconcept, job satisfaction, and retention of nurses. International Journal of Nursing Studies, 45(10), 1449-1459.

Dalgarn, M. K. (2001). The role of the campus recreation center in creating a community. Recreational Sports Journal, 25(1), 66-72.

Ducharme, L. J., \& Martin, J. K. (2000). Unrewarding work, coworker support, and job satisfaction: A test of the buffering hypothesis. Work and occupations, 27(2), 223-243.

Dwyer, D. J., \& Ganster, D. C. (1991). The effects of job demands and control on employee attendance and satisfaction. Journal of Organizational Behavior, 12(7), 595-608.

Ehrenberg, R. G., \& Sherman, D. R. (1987). Employment while in college, academic achievement, and postcollege outcomes: A summary of results. Journal of Human Resources, 1-23. 
Faragher, E. B., Cass, M., \& Cooper, C. L. (2005). The relationship between job satisfaction and health: a meta-analysis. Occupational and Environmental Medicine, 62(2), 105-112.

Foli, K. J., Karagory, P. M., Gibson, G., \& Kirkpatrick, J. M. (2013). Developing a sense of community among nursing students. Nurse Educator, 38(6), 246-251.

Folkins, C., O'Reilly, C., Roberts, K., \& Miller, S. (1977). Physical environment and job satisfaction in a community mental health center. Community mental health journal, 13(1), 24-30.

Forrester, S. (2015). Benefits of collegiate recreational sports participation: Results from the 2013 NASPA assessment and knowledge consortium study. Recreational Sports Journal, 39(1), 2-15.

Franěk, M., \& Večeřa, J. (2008). Personal characteristics and job satisfaction. $E$ \& $M$ Ekonomie $a$ Management, 11(4), 63-76.

Frontz, H. O. (1978). Sources of job satisfaction and dissatisfaction among psychiatric aides. Psychiatric Services, 29(4), 229-230.

Furnham, A., Eracleous, A., \& Chamorro-Premuzic, T. (2009). Personality, motivation and job satisfaction: Hertzberg meets the Big Five. Journal of Managerial Psychology, 24(8), 765779.

Ganzach, Y. (2003). Intelligence, education, and facets of job satisfaction. Work and Occupations, 30(1), 97-122.

Ghiselli, R. F., La Lopa, J. M., \& Bai, B. (2001). Job satisfaction, life satisfaction, and turnover intent: Among food-service managers. Cornell Hotel and Restaurant Administration Quarterly, 42(2), 28-37. 
Glenn, N. D., \& Weaver, C. N. (1982). Further evidence on education and job satisfaction. Social Forces, 61(1), 46-55.

Glynn, T. J. (1981). Psychological sense of community: Measurement and application. Human Relations, 34(9), 789-818.

Gomez, E., Baur, J. W., Hill, E., \& Georgiev, S. (2015). Urban parks and psychological sense of community. Journal of Leisure Research, 47(3), 388-398.

Green, C., \& Heywood, J. S. (2008). Does performance pay increase job satisfaction? Economica, 75(300), 710-728.

Griffith, M. D., Walker, J. T., \& Collins, J. R. (2011). Examining differences in socialization opportunities among student work groups in a university recreation department. Recreational Sports Journal, 35(2), 107-116.

Hackman, J. R., \& Oldham, G. R. (1975). Development of the job diagnostic survey. Journal of Applied psychology, 60(2), 159-170.

Haines, D. J. (2001). Undergraduate student benefits from university recreation. Recreational Sports Journal, 25(1), 25-33.

Hall, D. A. (2006). Participation in a campus recreation program and its effect on student retention. Recreational Sports Journal, 30(1), 40-45.

Hariri, H., Monypenny, R., \& Prideaux, M. (2012). Principalship in an Indonesian school context: can principal decision-making styles significantly predict teacher job satisfaction? School Leadership \& Management, 32(5), 453-471.

Henchy, A. (2011). The influence of campus recreation beyond the gym. Recreational Sports Journal, 35(2), 174-181. 
Henchy, A. (2013). The perceived benefits of participating in campus recreation programs and facilities: A comparison between undergraduate and graduate students. Recreational Sports Journal, 37(2), 97-105.

Hesel, R. A. (2000). Intercollegiate athletics have little infl uence on college choice -Intramural and recreational opportunities matter more. Student Poll IV, 1-12. Art and Science Group, Baltimore, MD.

Hochwarter, W. A., Ferris, G. R., Perrewe, P. L., Witt, L. A., \& Kiewitz, C. (2001). A note on the nonlinearity of the age-job-satisfaction relationship. Journal of Applied Social Psychology, 31(6), 1223-1237.

Huesman Jr, R. L., Brown, A. K., Lee, G., Kellogg, J. P., \& Radcliffe, P. M. (2007). Modeling Student Academic Success: Does Usage of Campus Recreation Facilities Make a Difference? The National Symposium on Student Retention. Paper presented at 2007 National Symposium, Milwaukee, WI.

Huesman Jr, R., Brown, A. K., Lee, G., Kellogg, J. P., \& Radcliffe, P. M. (2009). Gym bags and mortarboards: Is use of campus recreation facilities related to student success? NASPA journal, 46(1), 50-71.

Iaffaldano, M. T., \& Muchinsky, P. M. (1985). Job satisfaction and job performance: A metaanalysis. Psychological Bulletin, 97(2), 251.

Ilies, R., \& Judge, T. A. (2004). An experience-sampling measure of job satisfaction and its relationships with affectivity, mood at work, job beliefs, and general job satisfaction. European Journal of Work and Organizational Psychology, 13(3), 367-389. 
Ioannou, P., Katsikavali, V., Galanis, P., Velonakis, E., Papadatou, D., \& Sourtzi, P. (2015). Impact of job satisfaction on Greek nurses' health-related quality of life. Safety and Health At Work, 6(4), 324-328.

Ivancevich, J. M., \& Matteson, M. T. (1980). Optimizing human resources: a case for preventive health and stress management. Organizational Dynamics, 9(2), 5-25.

Jacobs, R., \& Solomon, T. (1977). Strategies for enhancing the prediction of job performance from job satisfaction. Journal of Applied Psychology, 62(4), 417.

Jex, S. M., \& Beehr, T. A. (1991). Emerging theoretical and methodological issues in the study of work-related stress. Research in Personnel and Human Resources Management, 9(31), 1365.

Jones, I. (2015). Research methods for sports studies. Routledge (4th ed.). New York, NY:

Judge, T. A., \& Watanabe, S. (1993). Another look at the job satisfaction-life satisfaction relationship. Journal of applied psychology, 78(6), 939-948.

Judge, T. A., Bono, J. E., \& Locke, E. A. (2000). Personality and job satisfaction: The mediating role of job characteristics. Journal of Applied Psychology, 85(2), 237.

Judge, T. A., Piccolo, R. F., Podsakoff, N. P., Shaw, J. C., \& Rich, B. L. (2010). The relationship between pay and job satisfaction: A meta-analysis of the literature. Journal of Vocational Behavior, 77(2), 157-167.

Judge, T. A., Thoresen, C. J., Bono, J. E., \& Patton, G. K. (2001). The job satisfaction-job performance relationship: A qualitative and quantitative review. Psychological bulletin, 127(3), 376-407.

Kaltenbaugh, L. P. (2009). A study on job satisfaction among campus recreation administrators at four-year public and private institutions. Recreational Sports Journal, 33(2), 89-101. 
Kampf, S. (2010). Impact of college recreation centers on enrollment. Recreational Sports Journal, 34(2), 112-118.

Kampf, S. (2013). Human resources. In NIRSA (Ed.), Campus recreational sports: Managing employees, programs, facilities, and services (pp. 163-182). Champaign, IL: Human Kinetics.

Kampf, S., \& Teske, E. J. (2013). Collegiate recreation participation and retention. Recreational Sports Journal, 37(2), 85-96.

Kearney, J. S., \& Tingle, J. K. (1998). Evaluation of Student Employees: Why, Who, How, When, What and Where. Recreational Sports Journal, 22(3), 45-49.

Kellison, T. B., \& James, J. D. (2011). Factors influencing job satisfaction of student employees of a recreational sports department at a large, four-year public institution: A case study. Recreational Sports Journal, 35(1), 35-44.

Kinzl, J. F., Knotzer, H., Traweger, C., Lederer, W., Heidegger, T., \& Benzer, A. (2004). Influence of working conditions on job satisfaction in anaesthetists. British Journal of Anaesthesia, 94(2), 211-215.

Kirmeyer, S. L. (1988). Observed communication in the workplace: Content, source, and direction. Journal of community psychology, 16(2), 175-187.

Klein, K. J., \& D'Aunno, T. A. (1986). Psychological sense of community in the workplace. Journal of Community Psychology, 14(4), 365-377.

Krausz, M., Sagie, A., \& Bidermann, Y. (2000). Actual and preferred work schedules and scheduling control as determinants of job-related attitudes. Journal of vocational behavior, 56(1), 1-11. 
Krithikadatta, J. (2014). Normal distribution. Journal of conservative dentistry: JCD, 17(1), 9697.

Lambert, S. J., \& Hopkins, K. (1995). Occupational conditions and workers' sense of community: Variations by gender and race. American Journal of Community Psychology, 23(2), 151-179.

Lampinen, M. S., Viitanen, E. A., \& Konu, A. I. (2015). Sense of community and job satisfaction among social and health care managers. Leadership in Health Services, 28(3), 228-244.

Lee, R., \& Wilbur, E. R. (1981). Age, education, job tenure, salary, job characteristic and job satisfaction. Journal of Vocational Behavior, 18, 362-373.

Lee, R., \& Wilbur, E. R. (1985). Age, education, job tenure, salary, job characteristics, and job satisfaction: A multivariate analysis. Human Relations, 38(8), 781-791.

Legg, E., Wells, M. S., \& Barile, J. P. (2015). Factors related to sense of community in youth sport parents. Journal of Park and Recreation Administration, 33(2), 73-86.

Lindsey, R., \& Sessoms, E. (2006). Assessment of a campus recreation program on student recruitment, retention, and frequency of participation across certain demographic variables. Recreational Sports Journal, 30(1), 30-39.

Locke, E. A. (1976). The nature and causes of job satisfaction. In M. Dunnette (Ed.), Handbook of industrial and organizational psychology (pp. 1279-1319). Chicago, IL: Rand McNally.

Lund, D. B. (2003). Organizational culture and job satisfaction. Journal of Business \& Industrial Marketing, 18(3), 219-236.

Mahipalan, M., \& Sheena, S. (2018). Mediating Effect of Engagement on Workplace Spirituality-Job Involvement Relationship: A Study among Generation Y Professionals. Asia-Pacific Journal of Management Research and Innovation, 14(1-2), 1-9. 
McCalister, K. T., Dolbier, C. L., Webster, J. A., Mallon, M. W., \& Steinhardt, M. A. (2006). Hardiness and support at work as predictors of work stress and job satisfaction. American Journal of Health Promotion, 20(3), 183-191.

McFadden, C. W., \& Carr, J. W. (2015). Collegiate recreation student employee as student leader. New Directions for Student Leadership, 2015(147), 65-76.

McGinty, A. S., Justice, L., \& Rimm-Kaufman, S. E. (2008). Sense of school community for preschool teachers serving at-risk children. Early Education and Development, 19(2), 361384.

McInnerney, J. M., \& Roberts, T. S. (2004). Online learning: Social interaction and the creation of a sense of community. Journal of Educational Technology \& Society, 7(3), 73-81.

McMillan, D. W. (2011). Sense of community, a theory not a value: A response to Nowell and Boyd. Journal of community psychology, 39(5), 507-519.

McMillan, D. W., \& Chavis, D. M. (1986). Sense of community: A definition and theory. Journal of Community Psychology, 14(1), 6-23.

Miller, J. J. (2011). Impact of a university recreation center on social belonging and student retention. Recreational Sports Journal, 35(2), 117-129.

Milliman, J., Czaplewski, A. J., \& Ferguson, J. (2003). Workplace spirituality and employee work attitudes: An exploratory empirical assessment. Journal of organizational change management, 16(4), 426-447.

Mobley, W. H., Griffeth, R. W., Hand, H. H., \& Meglino, B. M. (1979). Review and conceptual analysis of the employee turnover process. Psychological Bulletin, 86(3), 493-522.

Mull, R. F., Bayless, K. G., \& Jamieson, L. M. (2005). Recreational sport management (4th ed.). Champaign, IL: Human Kinetics 
Newstrom J.W. (1986). Human behavior at work. New York. McGraw-Hill.

Ng, T. W., \& Feldman, D. C. (2010). Organizational tenure and job performance. Journal of management, 36(5), 1220-1250.

Northey, W.F., Jr. (2005). Studying marriage and family therapists in the 21 st century: Methodological and technological issues. Journal of Marital \& Family Therapy, 31(1), 99105.

Nulty, D. D. (2008). The adequacy of response rates to online and paper surveys: what can be done?. Assessment \& evaluation in higher education, 33(3), 301-314.

Omar-Fauzee, M. S., Yusof, A., \& Zizzi, S. (2009). College students' attitude towards the utilization of the sport recreation center (SRC). European Journal of Social Sciences, 7(3), $27-40$.

Pack, S. M., Jordan, J. S., Turner, B. A., \& Haines, D. (2007). Perceived organizational support and employee satisfaction and retention. Recreational Sports Journal, 31(2), 95-106.

Parsons, J., Kaltenbaugh, L. P., Brubaker, K., Winters, B., \& Cali, S. (2013). A preliminary investigation of job satisfaction of compliance officers at NCAA Division II institutions. The Journal of SPORT, 2(2), 154-174.

Pierce, J. L., \& Newstrom, J. W. (1982). Employee responses to flexible work schedules: An inter-organization, inter-system comparison. Journal of Management, 8(1), 9-25.

Porter, L. W., \& Steers, R. M. (1973). Organizational, work, and personal factors in employee turnover and absenteeism. Psychological Bulletin, 80(2), 151.

Pretty, G. M., \& McCarthy, M. (1991). Exploring psychological sense of community among women and men of the corporation. Journal of Community Psychology, 19(4), 351-361. 
Pretty, G. M., McCarthy, M. E., \& Catano, V. M. (1992). Psychological environments and burnout: Gender considerations within the corporation. Journal of Organizational Behavior, 13(7), 701-711.

Randhawa, G. (2007). Relationship between job satisfaction and turnover intentions: An empirical analysis. Indian Management Studies Journal, 11(2), 149-159.

Rhodes, S. R. (1983). Age-related differences in work attitudes and behavior: A review and conceptual analysis. Psychological bulletin, 93(2), 328-367.

Roddy, L., Pohle-Krauza, R. J., \& Geltz, B. (2017). Recreation center utilization affects academic outcomes. Recreational Sports Journal, 41(1), 67-75.

Ross, C. M., Young, S. J., Sturts, J. R., \& Kim, K. T. (2014). Personal Correlates Impacting Job Satisfaction Among Campus Recreational Sport Employees. International Journal of Sport Management, Recreation \& Tourism, 14.

Rossi, R. J., \& Stringfield, S. C. (1995). What we must do for students placed at risk. The Phi Delta Kappan, 77(1), 73-76.

Rovai, A. P. (2002). Sense of community, perceived cognitive learning, and persistence in asynchronous learning networks. The Internet and Higher Education, 5(4), 319-332.

Rovai, A. P., \& Jordan, H. M. (2004). Blended learning and sense of Community: a comparative analysis with traditional and fully online graduate courses. International Review of Research in Open and Distance Learning, 5(2), 1-12.

Royal, M. A., \& Rossi, R. J. (1996). Individual-level correlates of sense of community: Findings from workplace and school. Journal of Community Psychology, 24(4), 395-416.

Sarason, S. B. (1974). The psychological sense of community: Prospects for a community psychology. San Francisco, CA: Jossey-Bass. 
Sarata, B. P. V., \& Jeppesen, J. C. (1977). Job design and staff satisfaction in human service settings. American Journal of Community Psychology, 5(2), 229.

Sarker, S. J., Crossman, A., \& Chinmeteepituck, P. (2003). The relationships of age and length of service with job satisfaction: an examination of hotel employees in Thailand. Journal of managerial Psychology.

Scanlan, J. N., \& Still, M. (2013). Job satisfaction, burnout and turnover intention in occupational therapists working in mental health. Australian Occupational Therapy Journal, 60(5), 310-318.

Schonlau, M., Fricker Jr., R.D., \& Elliott, M.N. (2001). Conducting Research Surveys via E-mail and the Web. Santa Monica, CA: Rand Corporation Retrieved January 17, 2005, from http://www.rand.org publications/MR/MR1480/.

Schuler, R. S. (1975). Sex, organizational level, and outcome importance: Where the differences are. Personnel Psychology, 28, 365-378.

Singh, P., \& Loncar, N. (2010). Pay satisfaction, job satisfaction and turnover intent. Relations industrielles/industrial relations, 65(3), 470-490.

Siu, O. L. (2002). Predictors of job satisfaction and absenteeism in two samples of Hong Kong nurses. Journal of advanced nursing, 40(2), 218-229.

Sloane, P. J., \& Williams, H. (2000). Job satisfaction, comparison earnings, and gender. Labour, 14(3), 473-502.

Smith, P. C., Kendall, L. M., \& Hulin, C. (1969). The measurement of satisfaction in work and behavior. Chicago: Rand McNally.

Spector, P. E. (1985). Measurement of human service staff satisfaction: Development of the job satisfaction survey. American Journal of Community Psychology, 13(6), 693-713. 
Stier Jr, W. F., Schneider, R. C., Kampf, S., \& Gaskins, B. P. (2010). Job satisfaction for campus recreation professionals within NIRSA institutions. Recreational Sports Journal, 34(2), 7894.

Templer, K. J. (2012). Five-factor model of personality and job satisfaction: The importance of agreeableness in a tight and collectivistic Asian society. Applied Psychology, 61(1), 114129.

Tinto, V. (1975). Dropout from higher education: A theoretical synthesis of recent research. Review of Educational Research, 45(1), 89-125.

Todd, M. K., Czyszczon, G., Carr, J. W., \& Pratt, C. (2009). Comparison of health and academic indices between campus recreation facility users and nonusers. Recreational Sports Journal, 33(1), 43-53.

Warner, S., \& Leierer, S. (2015). Building community via sport for adolescents. Journal of Applied Sport Management, 7(4). 84-99.

Weiss, D. J., Dawis, R. V., England, G. W., \& Lofquist, L. H. (1967). Minnesota studies in vocational rehabilitation. Manual for the Minnesota Satisfaction Questionnaire, 22, 23-4.

Weiss, H. M., \& Cropanzano, R. (1996). Affective events theory: A theoretical discussion of the structure, causes and consequences of affective experiences at work. Research in Organizational Behavior, 18, 1-74

Winter-Collins, A., \& McDaniel, A. M. (2000). Sense of belonging and new graduate job satisfaction. Journal for Nurses in Professional Development, 16(3), 103-111.

Wolf-Wendel, L., Ward, K., \& Kinzie, J. (2009). A tangled web of terms: The overlap and unique contribution of involvement, engagement, and integration to understanding college student success. Journal of College Student Development, 50(4), 407-428. 
Wood, L., Frank, L. D., \& Giles-Corti, B. (2010). Sense of community and its relationship with walking and neighborhood design. Social Science \& Medicine, 70(9), 1381-1390.

Wright, T. A., \& Bonett, D. G. (2007). Job satisfaction and psychological well-being as nonadditive predictors of workplace turnover. Journal of Management, 33(2), 141-160.

Yasuda, T. (2009). Psychological sense of community in university classrooms: Do achievement goal orientations matter?. College Student Journal, 43(2), 547-562.

Zaharia, E. S., and Baumeister, A. A. (1979). Cross-organizational job satisfactions of technician-level staff members. American journal of mental deficiency, 82, 580-593.

Zhang, J. J., DeMichele, D. J., \& Connaughton, D. P. (2004). Job satisfaction among mid-level collegiate campus recreation program administrators. Journal of Sport Behavior, 27(2), 184-212.

Zhang, J. J., DeMichele, D. J., \& Connaughton, D. P. (2004). Job Satisfaction Among Mid-level Collegiate Campus Recreation Program Administrators. Journal of Sport Behavior, 27(2), 184-212.

Zizzi, S., Ayers, S. F., Watson, J. C., \& Keeler, L. (2004). Assessing the impact of new student campus recreation centers. NASPA Journal, 41(4), 588-630. 


\section{APPENDIX A: QUESTIONNAIRE}

\section{Sense of Community, Job Satisfaction, Employees at the Campus Recreation Center}

\section{Please read through the consent form and check the box at the bottom to proceed with this}

study if you are willing to participate. If you do not want to participate, you can close the survey.

\section{Participant Concent Form}

The purpose of this study is to examine the relationship between sense of community and job satisfaction among employees working at Campus Recreation Center. You have been invited to participate because you work at a campus recreation center. This study is conducted by Mina Woo under the supervision of Dr. Yun Chang at the School of Kinesiology and Recreation at Illinois State University.

\section{Why are you being asked?}

You have been invited to participate because you work at a campus recreation center. You are ineligible to participate if you are under the age of 18 . Your participation in this study is voluntary. You will not be penalized if you choose to skip parts of the study, not participate, or withdraw from the study at any time.

What would you do?

If you choose to participate in this study, you will be asked to provide your opinion about various research scenarios in an online survey. In total, your involvement in this study will last approximately 10 minutes.

\section{Are any risks expected?}

We do not anticipate any risks beyond those that would occur in everyday life

\section{Will your information be protected?}

Your responses in the survey will be anonymous; nothing that will identify you will be linked to your responses. The findings from this study may be presented in conferences, meetings, and publications. When these findings are presented, your responses will be combined with the responses of other participants.

Who will benefit from this study?

While you may not directly benefit from this study, your responses will help inform best research practices and develop guidelines for ethical research

Whom do you contact if you have any questions?

If you have any questions about the research, contact Mina Woo at mwoo12@ilstu.edu or Dr. Yun Chang at ychan12@ilstu.edu.

If you have any questions about your rights as a participant, or if you feel you have been placed at risk, contact the Illinois State

University Research Ethics \& Compliance Office at (309) 438-5527 or IRB@ilstu.edu. 
You can print this form for your records.

I am 18 or older and willing to participate in this study

The Job Satisfaction Survey

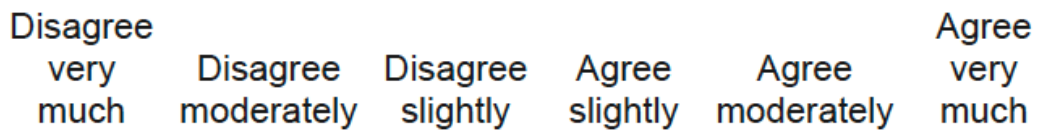

1. I feel I am being paid a fair amount for the work I do.
O
O
O
$\bigcirc$

2. There is really too little chance for promotion on my job.

3. My supervisor is quite competent in doing his/her job.

\section{I am not} satisfied with the benefits I receive.

O<smiles>[C+]1CCCCC1</smiles><smiles>O</smiles><smiles>O</smiles><smiles>[O-]</smiles><smiles>O</smiles><smiles>c1ccccc1</smiles><smiles>[C+]1CCCCC1</smiles><smiles>O</smiles><smiles>c1ccccc1</smiles>

5. When I do a good job, I receive the recognition for it that I should receive.

6. Many of our rules and procedures make doing a good job difficult.

7. I like the people I work with.

$\begin{array}{lll}0 & 0 & 0 \\ 0 & 0 & 0 \\ 0 & 0 & 0\end{array}$




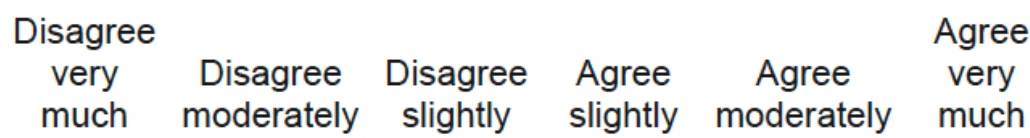

8. I sometimes feel my job is meaningless.

$\begin{array}{cccccc} & 0 & O & O & \bigcirc & \bigcirc \\ \begin{array}{c}\text { Disagree } \\ \text { very } \\ \text { much }\end{array} & \begin{array}{c}\text { Disagree } \\ \text { moderately }\end{array} & \begin{array}{c}\text { Disagree } \\ \text { slightly }\end{array} & \begin{array}{c}\text { Agree } \\ \text { slightly }\end{array} & \begin{array}{c}\text { Agree } \\ \text { moderately }\end{array} & \begin{array}{c}\text { Agree } \\ \text { very } \\ \text { much }\end{array}\end{array}$

9. Communications seem good within this organization.
O
O
O
O
O

10. Raises are too few and far between.

$\mathrm{O} O \mathrm{O}$

O

O

O

11. Those who do well on the job stand a fair chance of being promoted.

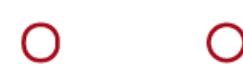

O

O

O

12. My supervisor is unfair to me.
O

○

$\bigcirc$

O

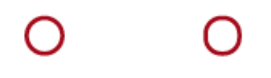

The Job Satisfaction Survey

$\begin{array}{cccccc}\begin{array}{c}\text { Disagree } \\ \text { very }\end{array} & \text { Disagree } & \text { Disagree } & \text { Agree } & \text { Agree } & \begin{array}{c}\text { Agree } \\ \text { very } \\ \text { much }\end{array} \\ \text { moderately } & \text { slightly } & \text { slightly } & \text { moderately } & \text { much }\end{array}$

13. The benefits we receive are as good as most other

O

O

O

O

O organizations offer.

14. I do not feel that the work I do is appreciated.

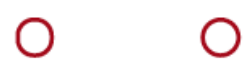

O

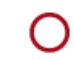

$\bigcirc$

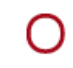




$\begin{array}{cccccc}\begin{array}{c}\text { Disagree } \\ \text { very }\end{array} & \text { Disagree } & \text { Disagree } & \text { Agree } & \text { Agree } & \text { Agree } \\ \text { much } & \text { moderately } & \text { slightly } & \text { slightly } & \text { moderately } & \text { much }\end{array}$

15. My efforts to do a good job are seldom blocked by red tape.

16. I find I have to work harder at my job than I should because of the incompetence of people I work with.

17. I like doing the things I do at work.

$\begin{array}{cccccc}\begin{array}{c}\text { Disagree } \\ \text { very }\end{array} & \text { Disagree } & \text { Disagree } & \text { Agree } & \text { Agree } & \text { Agree } \\ \text { much } & \text { moderately } & \text { slightly } & \text { slightly } & \text { moderately } & \text { much }\end{array}$

18. The goals of this organization are not clear to me.

19. I feel unappreciated by the organization when I think about what they pay me.
O
O
O
O

$\bigcirc \quad \bigcirc$

20. People get ahead as fast here as they do in other places.

O $0 \quad 0 \quad 0 \quad 0 \quad 0$

$\begin{array}{llllll}0 & 0 & 0 & 0\end{array}$

21. My supervisor

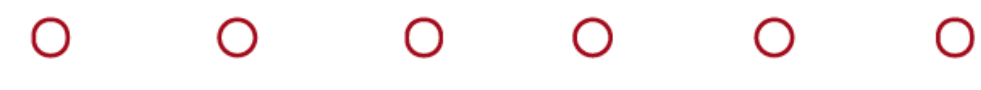

$\begin{array}{cccccc}\begin{array}{c}\text { Disagree } \\ \text { very }\end{array} & \text { Disagree } & \text { Disagree } & \text { Agree } & \text { Agree } & \text { Agree } \\ \text { much } & \text { moderately } & \text { slightly } & \text { slightly } & \text { moderately } & \text { much }\end{array}$
shows too little interest in the feelings of subordinates. 
Qualtrics Survey Software

$\begin{array}{cccccc}\begin{array}{c}\text { Disagree } \\ \text { very }\end{array} & \text { Disagree } & \text { Disagree } & \text { Agree } & \text { Agree } & \text { Agree } \\ \text { much } & \text { moderately } & \text { slightly } & \text { slightly } & \text { moderately } & \text { much }\end{array}$

22. The benefit package we have is equitable.

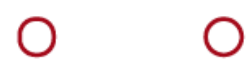

23. There are few rewards for those who work here.
O
O

O

O

$\mathrm{O}$

24. I have too much to do at work.

O $\mathrm{O}$

O

O<smiles>O</smiles>

0

The Job Satisfaction Survey

25. I enjoy my coworkers.

\begin{tabular}{|c|c|c|c|c|}
\hline $\begin{array}{l}\text { Disagree } \\
\text { very } \\
\text { much }\end{array}$ & $\begin{array}{l}\text { Disagree } \\
\text { moderately }\end{array}$ & $\begin{array}{l}\text { Disagree } \\
\text { slightly }\end{array}$ & $\begin{array}{l}\text { Agree } \\
\text { slightly }\end{array}$ & $\begin{array}{c}\text { Agree } \\
\text { moderately }\end{array}$ \\
\hline
\end{tabular}

26. I often feel that I do not know what is going on with the organization.

27. I feel a sense of pride in doing my job.
O
O

O

O

$\mathrm{O}$

28. I feel satisfied with my chances for salary increases.

O

$\bigcirc$<smiles>[C+]1CCCCC1</smiles><smiles>O</smiles><smiles>[O]</smiles><smiles>O</smiles>

0

O<smiles>[C-]1CCCCC1</smiles>

0

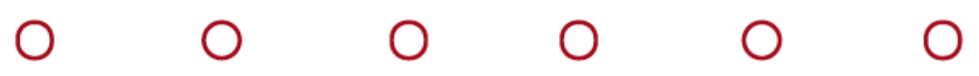

\begin{tabular}{|c|c|c|c|c|}
\hline $\begin{array}{c}\text { Disagree } \\
\text { very } \\
\text { much }\end{array}$ & $\begin{array}{l}\text { Disagree } \\
\text { moderately }\end{array}$ & $\begin{array}{l}\text { Disagree } \\
\text { slightly }\end{array}$ & $\begin{array}{l}\text { Agree } \\
\text { slightly }\end{array}$ & $\begin{array}{c}\text { Agree } \\
\text { moderately }\end{array}$ \\
\hline
\end{tabular}

29. There are benefits we do not have which we should have.

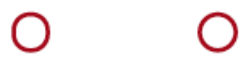

0
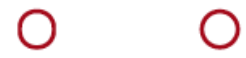

0 


\begin{tabular}{|c|c|c|c|c|}
\hline $\begin{array}{c}\text { Disagree } \\
\text { very } \\
\text { much }\end{array}$ & $\begin{array}{l}\text { Disagree } \\
\text { moderately }\end{array}$ & $\begin{array}{l}\text { Disagree } \\
\text { slightly }\end{array}$ & $\begin{array}{l}\text { Agree } \\
\text { slightly }\end{array}$ & $\begin{array}{c}\text { Agree } \\
\text { moderately }\end{array}$ \\
\hline
\end{tabular}

30. I like my supervisor.
O
O

31. I have too much paperwork.

O $\mathrm{O}$

32. I don't feel my efforts are rewarded the way they should be.

$\begin{array}{cccccc}\text { O } & \mathrm{O} & \mathrm{O} & \mathrm{O} & \mathrm{O} & \mathrm{O} \\ \begin{array}{c}\begin{array}{c}\text { visagree } \\ \text { much }\end{array} \\ \text { much }\end{array} & \begin{array}{c}\text { Disagree } \\ \text { moderately }\end{array} & \begin{array}{c}\text { Disagree } \\ \text { slightly }\end{array} & \begin{array}{c}\text { Agree } \\ \text { slightly }\end{array} & \begin{array}{c}\text { Agree } \\ \text { moderately }\end{array} & \begin{array}{c}\text { Agree } \\ \text { very } \\ \text { much }\end{array}\end{array}$

33.I am satisfied with my chances for promotion.
0
O
O
O
O

34. There is too much bickering and fighting at work.

35. My job is enjoyable.

36. Work assignments are not fully explained.

O $\mathrm{O}$

O $\mathrm{O}$

O $\mathrm{O}$
O

$\mathrm{O}$

0
O<smiles>O</smiles>

O

O

O

O

O

0

\section{Sense of Community Index 2}

\section{The following questions about community refer to campus recreation center where you work.}

How important is it to you to feel a sense of community with other community members?

Prefer Not to be Part of This Community 
Not Important at All

Not Very Important

$\bigcirc$ Somewhat Important

Important

Very Important

How well do each of the following statements represent how you feel about this community?

Not at all Somewhat Mostly Completely

1. I get important needs of mine met

5. When I have a problem, I can talk about it with members of this community.

6. People in this community have similar needs, priorities, and goals.

O

O
0

O
0

$O$ because I am part of this community.

2. Community members and I
value the same
things.
3. This community
has been success
in getting the need
of its members met.
4. Being a member
of this community
makes me feel
good. members and I
value the same
things.
3. This community
has been success
in getting the need
of its members met.
4. Being a member
of this community
makes me feel
good. members and I
value the same
things.
3. This community
has been success
in getting the need
of its members met.
4. Being a member
of this community
makes me feel
good. members and I
value the same
things.
3. This community
has been successful
in getting the needs
of its members met.
4. Being a membe
of this community
makes me feel
good. members and I
value the same
things.
3. This community
has been successful
in getting the needs
of its members met.
4. Being a member
of this community
makes me feel
good. members and I
value the same
things.
3. This community
has been successfu
in getting the needs
of its members met.
4. Being a member
of this community
makes me feel
good. members and I
value the same
things.
3. This community
has been successful
in getting the needs
of its members met.
4. Being a member
of this community
makes me feel
good. members and I
value the same
things.
3. This community
has been successfu
in getting the needs
of its members met
4. Being a member
of this community
makes me feel
good. members and I
value the same
things.
3. This community
has been success
in getting the need
of its members met.
4. Being a member
of this community
makes me feel
good. members and I
value the same
things.
3. This community
has been success
in getting the need
of its members met.
4. Being a member
of this community
makes me feel
good. members and I
value the same
things.
3. This community
has been success
in getting the need
of its members met.
4. Being a member
of this community
makes me feel
good.
O

O

0

0

Not at all Somewhat
0

0

0

0

Mostly

Completely<smiles>[CH-]CO</smiles><smiles>O</smiles>

$O$<smiles>O</smiles>

. 
7. I can trust people in this community.

8. I can recognize most of the members of this community.

9. Most community members know me.

10. This community has symbols and expressions of membership such as clothes, signs, art, architecture, logos, landmarks, and flags that people can recognize.

11. I put a lot of time and effort into being part of this community.

12. Being a member of this community is a part of my identity.
O
O
O

Not at all

Somewhat

Mostly

Completely

O

O

O

O
0

O

0
O

O

0
0

$O$

O

0

0

How well do each of the following statements represent how you feel about this community?

Not at all Somewhat Mostly Completely

13. Fitting into this community is important to me.

O

14. This community can influence other communities. 
15. I care about what other community members think of me.

16. I have influence over what this community is like.

17. If there is a problem in this community, members can get it solved.

18. This community has good leaders.

19. It is very important to me to be a part of this community.

20. I am with other community members a lot and enjoy being with them.

21. I expect to be a part of this community for a long time.

22. Members of this community have shared important events together, such as holidays, celebrations, or disasters.
Not at all Somewhat Mostly Completely
O

O

Mostly

Completely
$\mathrm{O} \quad \mathrm{O}$

O $\quad 0$

O

O

O

$\mathrm{O}$
Not at all Somewhat Mostly Completely

O

O

0

0 
23. I feel hopeful about the future of this community.

O

O
O

O community care about each other.

What is your Gender?

Male

Female

Non-binary

What is your job position?

Student employee (Not including graduate assistant)

Student employee (Including graduate assistant)

Part-time employee (Non-student employee and Non-graduate assistant)

Full-time employee (Non-student employee and Non-graduate assistant)

How long have you been working at this campus recreation center?

Less than 1 year

1 - 4 years

5 - 7 years

Above 7 years

Powered by Qualtrics 